originalni

naučni

rad

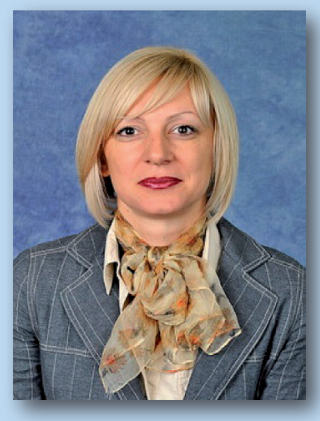

dr Milena Jakšić

Ekonomski fakultet, Univerziteta u Kragujevcu milenaj@kg.ac.rs

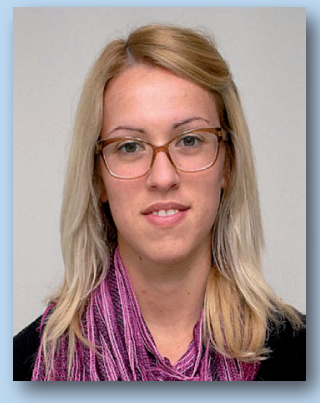

Jelena Purić puricjelena1@gmail.com
Rad primljen: 14.04 .2014 Odobren za štampu: 29.09.2014

\title{
UPOREDNA ANALIZA
} POSLOVANJA \section{BEOGRADSKE,} ZAGREBAČKE I VARŠAVSKE BERZE

Ovaj rad je deo interdisciplinarnog istraživačkog Projekta (broj 41010), koji finansira Ministarstvo nauke Republike Srbije

\section{Rezime}

U tržišno orijentisanim finansijskim sistemima brojne finansijske institucije posreduju $u$ procesu indirektnog finansiranja ili pružaju usluge $\mathrm{u}$ procesu direktnog finansiranja. Njihova struktura i funkcije su uslovljene institucionalnim specifičnostima i stepenom razvijenosti finansijskog sistema. U tranzitornim ekonomijama izgradnja finansijskog sistema, u skladu sa potrebama tržišne privrede, je podrazumevala, između ostalog, formiranje prethodno nepostojećih finansijskih institucija - nedepozitnih finansijskih posrednika i berzanskog tržišta. Berzansko tržište, kao sastavni deo finansijskog sistema, u zavisnosti od stepena privrednog i ukupnog društvenog razvoja, sa manje ili više uspeha usmerava finansijska sredstva između različitih grupa privrednih subjekata. S obzirom na to da postignut sklad između razuđenih finansijskih tokova i diversifikovanih finansijskih instrumenata predstavlja indikator razvijenosti tržišta kapitala, neosporna je potreba svake nacionalne ekonomije da sopstveni razvoj prilagodi zahtevima berzanskog tržišta. Imajući u vidu navedeno, u radu će biti ukazano na položaj Beogradske berze u odnosu na zemlje u okruženju, u periodu koji je obeležila globalna recesija. U cilju sagledavanja dostignutog nivoa razvoja tržišta kapitala u Srbiji, u radu se analiziraju Beogradska berza, Zagrebačka berza i Varšavska berza.

Ključne reči: Beogradska berza, Zagrebačka berza, Varšavska berza, BELEX15, CROBEX10, WIG30 


\section{COMPARATIVE}

\section{ANALYSIS OF}

\section{BELGRADE, ZAGREB}

\section{AND WARSAW STOCK EXCHANGES}

dr Milena Jakšić

Faculty of Economics, University of Kragujevac milenaj@kg.ac.rs

Jelena Purić puricjelena1@gmail.com Ministry of Science of the Republic of Serbia.

\section{Summary}

In market-oriented financial systems numerous financial institutions intermediate in the process of indirect financing or provide services in the process of direct financing. Their structure and functions are conditioned by institutional specificities and the level of the concerned financial system's development. The development of a financial system in transition economies, in line with the needs of market economy, requires, among other things, the formation of previously non-existent financial institutions - non-deposit financial intermediaries and stock exchange market. The stock exchange market, as an integral part of the financial system, depending on the level of economic and overall social development, more or less successfully channels financial funds towards various groups of economic entities. Given that the achieved balance among the diverse financial flows and diversified financial instruments indicates the level of capital market development, each national economy unquestionably needs to adjust its own development according to the stock exchange market requirements. Bearing in mind all of the above, this paper will indicate the position of the Belgrade Stock Exchange in relation to the countries in the region, in the period marked by the global recession. With a view to reviewing the achieved level of capital market development in Serbia, the paper analyzes Belgrade Stock Exchange, Zagreb Stock Exchange and Warsaw Stock Exchange.

Keywords: Belgrade Stock Exchange, Zagreb Stock Exchange, Warsaw Stock Exchange, BELEX15, CROBEX10, WIG30
Paper received: 14.04 .2014 Approved for publishing: 29.09.2014 


\section{Uvod}

U drugoj polovini XX veka globalni finansijski sistem je prošao kroz brojne promene koje su doprinele širenju aktivnosti finansijskih institucija i ekonomskom rastu. Tokom poslednje decenije XX veka, transformacija ekonomskih sistema u bivšim socijalističkim zemljama je podrazumevala korenite reforme njihovih finansijskih sistema. Reforme su između ostalog uključivale restrukturiranje domaćih i ulazak stranih banaka na domaća tržišta, osnivanje nedepozitnih finansijskih institucija, kao i oživljavanje berzanskog tržišta. To je nesumnjivo imalo pozitivne efekte na povećanje efikasnosti investicija i rast stope ekonomskog rasta. Međutim, globalna ekonomska kriza uzrokovana rastom kamatnih stopa, pogoršanjem bilansa banaka i preduzeća, padom cena hartija od vrednosti i povećanjem neizvesnosti dovela je do bankarske krize, valutne krize i krize poverenja, inicirajući problem informacione asimetrije. To je uticalo na rast sistemskog rizika, pad poverenja investitora, širenje finansijske nestabilnosti i smanjenje stope ekonomskog rasta.

Brojna istraživanja (Odedokun, 1996; Rousseau and Wachtel, 1998; Rousseau i Sylla, 2005; Burhop, 2006) pokazuju da razvoj finansijskog sistema generalno poboljšava ekonomski rast. Međutim, pojedina istraživanja (Calderón i Lui, 2003) pokazuju da je uticaj razvoja realnog sektora na razvoj finansijskog sistema značajniji u slučaju razvijenih zemalja. S druge strane, finansijski posrednici i tržište kapitala imaju veći relativni uticaj na ekonomski rast $\mathrm{u}$ manje razvijenim $\mathrm{u}$ odnosu na bolje razvijene zemlje, što $u$ dužem vremenskom periodu podrazumeva veći efekat razvoja finansijskog sistema vođenim razvojem tržišta kapitala na ekonomski rast.

Imajući $u$ vidu navedeno, predmet istraživanja biće usmeren na analizu berzanskog tržišta u finansijskom sistemu Srbije, Hrvatske i Poljske. Veličina srpskog tržišta kapitala u odnosu na posmatrane zemlje će se pozicionirati uz pomoć pokazatelja tržišne kapitalizacije (market capitalization ratio). Cilj istraživanja je da se izvrši sveobuhvatna analiza Beogradske, Zagrebačke i Varšavske berze $u$ periodu globalne recesije. Ključna hipoteza od koje se u radu polazi je: ukoliko je berzansko tržište razvijeno, finansijski sistem pruža mogućnost investitorima da optimalno alociraju slobodna finansijska sredstva. To, u krajnjoj instanci, doprinosi višoj stopi ekonomskog rasta.

\section{Beogradska berza}

Organizovano tržište dugoročnih hartija od vrednosti u Srbiji od 1992. godine funkcioniše pod nazivom Beogradska berza (Belgrade Stock Exchange - BSE). U savremenim uslovima poslovanja informacioni sistem, kadar i organizacija su doprineli da naličje Beogradske berze podseća na svetske berze. Međutim, realnost je da je domaće tržište kapitala nerazvijeno i da Beogradska berza zaostaje za nivoom razvijenosti berzi južne i istočne Evrope. Razvoj tržišta kapitala u Srbiji u velikoj meri je uslovljen kako istorijskim nasleđem, političkom nestabilnošću, tako i globalnom recesijom. Nedostatak kvalitetnih finansijskih instrumenata, neadekvatna institucionalna infrastruktura, politički i brojni drugi rizici uslovili su nizak prinos na ulaganja, pad prometa na Beogradskoj berzi, smanjenje učešća stranih investitora. Efekti globalne recesije dodatno su nepovoljno uticali na vrednost $\mathrm{i}$ promet hartija od vrednosti, a samim tim i na dubinu i likvidnost srpskog tržišta kapitala.

U odnosu na Varšavsku berzu (Warsaw Stock Exchange - WSE), koja ima veliki broj listiranih akcija, na BSE je taj broj sveden na osam. Osnovni razlog jeste različit način privatizacije velikih javnih preduzeća, koji je u Poljskoj sproveden putem inicijalne javne ponude (Initial Public Offering - IPO). Od 2004. godine, kada je Poljska ušla u EU, obavljeno je čak 308 inicijalnih javnih ponuda (Sieradzki, 2013: 11), dok je na Beogradskoj berzi IPO izostala.

Berza koja je u pogledu razvijenosti bliža WSE jeste Zagrebačka berza (Zagreb Stock Exchange - ZSE), preko koje je inicijalnom javnom ponudom privatizovan određen broj javnih preduzeća. To je pomoglo razvoju i očuvanju ove berze. Za razliku od BSE, gde postoji prime i standard market, na ZSE postoje tri segmenta regulisanog tržišta i to: redovno tržište (regular market), službeno tržište (official market) i vodeće tržište (prime market).

Uslovi za listing i kotaciju hartija od 


\section{Introduction}

In the second half of the $X X$ century, the global financial system underwent numerous changes that have contributed to the expansion of financial institutions' activities and overall economic growth. During the last decade of the $X X$ century, the transformation of economic systems in former socialist countries implied profound reforms of their financial systems. Among other things, the reforms involved the restructuring of domestic banks and the penetration of foreign banks into domestic markets, establishment of non-deposit financial institutions, and revival of the stock exchange market. This undoubtedly exerted some positive effects on the increase of investment efficiency and boosted the economic growth rate. However, the global economic crisis caused by the growth of interest rates, aggravated balance sheets of banks and companies, drop in securities prices and higher uncertainty, further generated the banking crisis, currency crisis and crisis in confidence, thereby initiating the problem of information asymmetry. This, in turn, led to the increase of systemic risk, lowered confidence of investors, escalation of financial instability and lower economic growth rate.

Numerous studies (Odedokun, 1996; Rousseau and Wachtel, 1998; Rousseau and Sylla, 2005; Burhop, 2006) have shown that the financial system's development in general boosts economic growth. Nevertheless, certain studies (Calderón and Lui, 2003) have indicated that the impact of the real sector's development on the financial system's development is more significant in case of developed countries. On the other hand, financial intermediaries and capital market have a higher relative impact on economic growth in less developed countries compared to more developed countries, which, in a longer time period, implies a bigger effect of the financial system's development fueled by capital market's development on economic growth.

Bearing in mind the above stated, the subject of this research will be focused on the analysis of the stock exchange market in the financial systems of Serbia, Croatia and Poland. The size of the Serbian capital market in relation to the observed countries will be positioned by means of the market capitalization ratio.
The objective of this research is to perform a comprehensive analysis of the Belgrade, Zagreb and Warsaw Stock Exchanges during the global recession. The key hypothesis that this paper is based upon is the following: if the stock exchange market is well developed, the financial system provides an opportunity for investors to optimally allocate free financial funds. Ultimately, this contributes to a higher economic growth rate.

\section{Belgrade Stock Exchange}

The organized long-term securities market in Serbia has been functioning since 1992 under the name of Belgrade Stock Exchange - BSE. In the contemporary business environment, its IT system, personnel and organization have contributed to the Belgrade Stock Exchange at first glance being similar to other stock exchanges in the world. However, in reality the domestic capital market is underdeveloped, and the Belgrade Stock Exchange falls behind the level of development of South and Eastern European stock exchanges. The development of the capital market in Serbia is largely conditioned by historical heritage, political instability and global recession. A lack of quality financial instruments, inadequate institutional infrastructure, political and numerous other risks, have caused low return on investments, reduced turnover at the Belgrade Stock Exchange, and decreased participation of foreign investors. The effects of the global recession have had an additional, adverse effect on the value and turnover of securities, and thereby the depth and liquidity of the Serbian capital market.

As opposed to the Warsaw Stock Exchange WSE, with a large number of listed shares, at the BSE this number has been reduced to no more than eight. The main reason is the different way of privatization of large public companies, which was in Poland implemented by means of Initial Public Offering - IPO. Since 2004, when Poland joined the EU, 308 initial public offerings have been performed (Sieradzki, 2013: 11), whereas the IPOs never even happened at the Belgrade Stock Exchange.

A stock exchange closer to the WSE in terms of its development level is Zagreb Stock 
vrednosti i drugih finansijskih instrumenata na Beogradskoj berzi propisuju se Pravilnikom o listingu i kotaciji hartija od vrednosti, dok saglasnost daje Komisija za hartije od vrednosti. Na svojoj internet stranici i najmanje u jednom dnevnom listu dostupnom na čitavoj teritoriji Srbije, Berza dnevno objavljuje listu izdavalaca i vrstu hartija od vrednosti i drugih finansijskih instrumenata za koje je donela rešenja o prijemu na listing. Kriterijumi za listiranje akcija uglavnom su zasnovani na analizi bilansnih pozicija kompanija, ali obuhvataju i psihološke efekte koje investitori prenose na tržište (Malinić, 2009: 139).

Centralni registar, depo i kliring hartija od vrednosti obavlja poslove jedinstvene evidencije o zakonitim imaocima hartija od vrednosti i drugih finansijskih instrumenata i o pravima iz tih hartija. Takođe, obavlja poslove jedinstvene evidencije o pravima trećih lica na hartijama od vrednosti i drugim finansijskim instrumentima, kao i poslove kliringa i saldiranja hartija od vrednosti i saldiranja novčanih obaveza i potraživanja nastalih po osnovu poslova sa hartijama od vrednosti (Centralni registar, depo i kliring hartija od vrednosti - CrHoV, 2006).

Narodna banka Srbije (NBS) vrši kontrolu načina organizacije i funkcionisanja tržišta novca i kratkoročnih hartija od vrednosti kroz obavezu dostavljanja izveštaja o radu koji se odnose na pomenute finansijske instrumente i aktivnosti poslovnih banaka na finansijskom tržištu. Dužničkim hartijama od vrednosti koje izdaju RS i NBS može se trgovati na berzanskom tržištu bez posebnih uslova koje utvrđuje Berza za druge izdavaoce hartija od vrednosti, dok se hartije od vrednosti koje izdaju strana pravna lica mogu primiti na listing samo pod uslovima utvrđenim zakonom i aktima Berze. Jedan od važnih učesnika na tržištu kapitala u Srbiji jeste i Ministarstvo finansija, koje je odgovorno za pravni okvir rada tržišta hartija od vrednosti, to jest za donošenje i harmonizaciju zakona iz oblasti berzanskog poslovanja i hartija od vrednosti.

Trgovanje hartijama od vrednosti na berzanskim sastancima može biti organizovano jednom od sledećih metoda:

1. metodom preovlađujuće cene,

2. metodom kontinuiranog trgovanja i

3. metodom minimalne cene (samo u trgovanju akcijama na vanberzanskom tržištu, isključivo za akcije koje iznosi za trgovanje Akcijski fond i na njegov zahtev).

Tržišni nalozi se u periodu kontinuiranog trgovanja odmah realizuju, pod uslovom da ima ponude (u slučaju kupovine), odnosno, tražnje (u slučaju prodaje). U slučaju da na strani ponude nema naloga, a na strani tražnji se pojavi tržišni nalog, on automatski prelazi u limit nalog sa cenom koja je jednaka indikativnoj ili prethodno utvrđenoj ceni $\mathrm{u}$ toku trgovine. Isto važi i kada na strani tražnje ne postoje nalozi kupovine, a u ponudi se pojavi tržišni nalog prodaje.

Dva osnovna pokazatelja kretanja cena akcija na BSE jesu, kao što je poznato, BELEX15 i BELEXline. Vodeći indeks Beogradske berze BELEX15 ima za cilj da što preciznije prikaže kretanje cena akcija kojima se trguje metodom kontinuiranog trgovanja, a koje su ispunile kriterijume za ulazak $\mathrm{u}$ indeksnu korpu. Izračunavanje i objavljivanje indeksa BELEX15 obavlja se od oktobra 2005. godine svakog radnog dana Berze, $u$ realnom vremenu, od trenutka kada je ispunjen uslov za njegovo izračunavanje i publikovanje, pa do formiranja cena na zatvaranju, objavljeno je na sajtu Beogradske berze (Dugalić, Štimac, 2005: 258). Indeks meri promene cena (price index) akcija kojima se trguje metodom kontinuiranog trgovanja na regulisanom tržištu (Beogradska berza, 2012).

Indeks BELEX15 je prevashodno namenjen unapređenju investicionog procesa, kroz merenje performansi najlikvidnijeg segmenta srpskog tržišta kapitala, kao i kroz mogućnost upoređivanja četiri potencijalne investicione strategije prema indeksu. S druge strane, BELEX15 je dizajniran na način koji najbliže moguće opisuje tržišna kretanja najlikvidnijih akcija i može da služi kao podloga (underlying) za kreiranje strukturiranih proizvoda i derivata na domaćem i inostranom tržištu (Beogradska berza, 2012).

Cena akcija koja se koristi za izračunavanje indeksa BELEX15 je svaka cena akcija koja je formirana $u$ trgovanju akcijama koje čine indeksnu korpu, izuzev cena koje su ostvarene u blok transakcijama, od trenutka kada su se stekli uslovi za njegovo izračunavanje i publikovanje.

Indeks BELEX15 se izračunava upotrebom Lasprejerove formule: 
Exchange - ZSE, at which a certain number of public companies was privatized through initial public offering. That facilitated the growth and preservation of this stock exchange. As opposed to the BSE, which only has a prime and a standard market, the ZSE has three segments of the regulated market: regular market, official market and prime market.

The conditions for listing and quotation of securities and other financial instruments at the Belgrade Stock Exchange are prescribed by the Rules on Listing and Quotation of Securities, the relevant approval being granted by the Securities Commission. On its webpage, and in minimum one daily newspaper available at the entire territory of Serbia, the Stock Exchange publishes a daily list of issuers and type of securities and other financial instruments for which it passed the decision on approved listing. The criteria for listing shares are mostly based on the analysis of companies' balance sheet positions, but they also include the psychological effects transferred to the market by investors (Malinić, 2009: 139).

The Central Securities Registry, Depository and Clearing House performs the operations of uniform registration of lawful holders of securities and other financial instruments, including the rights granted to them by these securities. Moreover, it conducts the tasks of uniform registration of third parties' rights in respect of securities and other financial instruments, along with the clearing and settlement of securities, and settlement of cash liabilities and receivables having occurred in respect of securities operations (Central Securities Registry, Depository and Clearing House, 2006).

The National Bank of Serbia (NBS) controls the methods of organization and functioning of the money and short-term securities market, by imposing the obligation of submitting reports on operations related to the concerned financial instruments and activities of commercial banks at the financial market. Debt securities issued by the RS and NBS may be traded at the stock exchange market without any particular preconditions defined by the Stock Exchange for other securities issuers, whereas securities issued by foreign legal entities may be listed only under the conditions prescribed by the law and the Stock Exchange by-laws. One of the significant participants at the capital market in Serbia is the Ministry of Finance, which is responsible for the legal framework for the securities market functioning, i.e. the adoption and harmonization of laws in the field of stock exchange operations and securities.

Securities trading at stock exchange meetings can be organized according to one of the following methods:

1. Single Price Method;

2. Continuous Trading Method; and

3. Minimal Price Method (only when trading shares at the OTC market, exclusively shares offered for trading by the Shares Fund and upon its request).

In the period of continuous trading, market orders are effected immediately, provided that there is supply (in case of a purchase), i.e. demand (in case of a sale). In case that there are no orders on the supply side, and a market order appears on the demand side, it automatically turns into a limit order at the price equal to the indicative price or the price previously determined during the trade process. The same goes when there are no purchase orders on the demand side, and a sales market order appears in supply.

Two main indicators of trends demonstrated by the BSE shares prices are BELEX15 and BELEXline. The leading index of the Belgrade Stock Exchange, BELEX15, has the objective of indicating, as precisely as possible, the trends in prices of shares traded according to the continuous trading method, which have met the criteria for entering the index basket. Calculation and publication of the BELEX15 Index has been conducted since October 2005 on every working day of the Stock Exchange, in real time, from the moment the conditions are met for its calculation and publication, until the formation of closing prices, as stated on the BSE website (Dugalić, Štimac, 2005: 258). The index measures the changes in prices of shares traded according to the continuous trading method on the regulated market (Belgrade Stock Exchange, 2012).

BELEX15 Index is primarily targeted at enhancing the investment process, by measuring the performance of the most liquid segment of the Serbian capital market, and by enabling the comparison of four potential investment strategies in relation to the Index. 


$$
B E L E X 15=\frac{\sum_{\mathrm{i}=1}^{\mathrm{n}} \mathrm{C}(\mathrm{i}, \mathrm{t}) * \mathrm{~K}(\mathrm{i}, \mathrm{t}) * \mathrm{FFc} * \mathrm{Ai}}{d(t)}
$$

pri čemu su:

BELEX15 (t) - vrednost indeksa selektovanih hartija u trenutku $t$, zaokružena na dve decimale; $\mathrm{n}$ - broj izdavalaca čije akcije se nalaze $\mathrm{u}$ indeksnoj korpi - selektovane hartije su nepromenjive do momenta revizije;

i - brojač, koji uzima vrednosti od 1 do 15 i predstavlja određenog izdavaoca čije su akcije u indeksnoj korpi;

$\mathrm{C}(\mathrm{i}, \mathrm{t})$ - cena akcija izdavaoca $i$, u trenutku $t$, koja se uzima $u$ realnom vremenu iz sistema za trgovanje;

$\mathrm{K}(\mathrm{i}, \mathrm{t})$ - količina akcija izdavaoca $i$, $\mathrm{u}$ trenutku $t$; $\mathrm{d}(\mathrm{t})$ - vrednost delioca u trenutku $t$.

$F F c(i, t)$ - free float faktor izdavaoca $i$, u trenutku $t$; $A(i)$ - prilagođavajući faktor izdavaoca $i$ (ponder).

$\mathrm{Na}$ osnovu Lasprejerove formule vrši se svakodnevno izračunavanje vrednosti najlikvidnijeg indeksa BSE. U Tabeli 1 može se uočiti da najveće učešće $u$ korpi indeksa ima NIS a. d., Novi Sad, zatim slede AIK banka, Komercijalna banka i Energoprojekt holding. Napred navedene četiri kompanije imaju učešće u korpi indeksa Belex15 od 58,47\%.
Na Grafikonu 1 je predstavljeno kretanje indeksa BELEX15 u periodu od 14.02.2011. godine do 05.02.2014. godine. Ko što se može uočiti, on je u poslednje tri godine zabeležio pad od 200 indeksnih poena. Najviša vrednost dostignuta je 06.06.2011. godine od ukupno 824,51 indeksnih poena, dok je najniža vrednost indeksa dostignuta 25.07.2012. godine i iznosila je 426,8 indeksnih poena. Veliki broj faktora je uticao na pad vrednosti indeksa BELEX15, pa se pored svetske finansijske krize izdvaja, kao jedan od važnijih, izostajanje IPO prilikom procesa privatizacije. Niska likvidnost, visoka volatilnost i skroman promet su odlike hartija od vrednosti Beogradske berze.

Tabela 1: Korpa indeksa Belex15

\begin{tabular}{|l|r|r|}
\hline \multicolumn{1}{|c|}{ Izdavalac } & $\begin{array}{c}\text { Tržišna } \\
\text { kapitalizacija } \\
\text { (u RSD) }\end{array}$ & Učešće \\
\hline NIS a.d., Novi Sad & 145.286 .816 .400 & $20,87 \%$ \\
\hline AIK banka a.d., Niš & 14.780 .765 .304 & $15,67 \%$ \\
\hline Komercijalna banka a.d., Beograd & 14.370 .361 .500 & $11,57 \%$ \\
\hline Energoprojekt holding a.d., Beograd & 7.979 .843 .160 & $10,26 \%$ \\
\hline Aerodrom Nikola Tesla a.d., Beograd & 17.316 .121 .750 & $7,58 \%$ \\
\hline Soja protein a.d., Bečej & 9.235 .224 .880 & $7,30 \%$ \\
\hline Imlek a.d., Beograd & 26.041 .726 .800 & $4,90 \%$ \\
\hline Metalac a.d., Gornji Milanovac & 2.450 .040 .000 & $4,90 \%$ \\
\hline Galenika Fitofarmacija a.d., Zemun & 3.593 .040 .000 & $4,60 \%$ \\
\hline Messer Tehnogas a.d., Beograd & 5.198 .839 .870 & $2,56 \%$ \\
\hline Jedinstvo a.d., Sevojno & 1.447 .415 .250 & $2,38 \%$ \\
\hline Alfa plam a.d., Vranje & 2.185 .150 .000 & $1,88 \%$ \\
\hline Goša montaža a.d., Velika Plana & 771.007 .652 & $1,51 \%$ \\
\hline Veterinarski zavod Subotica a.d., Subotica & 1.789 .282 .320 & $0,82 \%$ \\
\hline
\end{tabular}

Izvor: Beogradska berza: Tržišna korpa indeksa BELEX15 na dan 21.1.2014. 
On the other hand, BELEX15 is designed in such a way as to closely describe the market trends of the most liquid shares, and may serve as the underlying instrument for the creation of structured products and derivatives on the domestic and foreign market (Belgrade Stock Exchange, 2012).

The share price used to calculate the BELEX15 Index is any share price formed in the process of trading shares from the index basket, excluding the prices achieved in block transactions, from the moment the conditions are met for its calculation and publication.

BELEX15 Index is calculated by means of the Laspreyres formula:

$$
\text { BELEX15 }=\frac{\sum_{\mathrm{i}=1}^{\mathrm{n}} \mathrm{C}(\mathrm{i}, \mathrm{t}) * \mathrm{~K}(\mathrm{i}, \mathrm{t}) * \mathrm{FFc} * \mathrm{Ai}}{d(t)}
$$

with:

BELEX15(t) - value of the selected securities index at the moment $t$, rounded up to two decimal places;

$\mathrm{n}$ - number of issuers whose shares are in the index basket - selected securities are unchangeable until the time for revision;

$\mathrm{i}$ - index of summation, taking values from 1 to 15 and referring to a certain issuer whose shares are in the index basket;

$C(i, t)$ - price of shares of the issuer $i$, at the moment $t$, obtained in real time from the trading system;

$K(i, t)$ - amount of shares of the issuer $i$, at the moment $\mathrm{t}$;

$d(t)$ - value of the numerator at the moment $t$.

$\operatorname{FFc}(i, t)$ - free float factor of the issuer $i$, at the moment $\mathrm{t}$;

A(i) - adjustment factor of the issuer $i$ (weight).

Based on the Laspreyres formula, the values of the most liquid BSE Index are calculated daily. Table 1 below indicates that the major share in the Index basket is held by NIS a.d, Novi Sad, followed by AIK Bank, Komercijalna Bank and Energoprojekt Holding. These four companies hold a share in the Belex15 Index basket amounting to $58.47 \%$.

Table 1: Belex15 Index Basket

\begin{tabular}{|l|r|r|}
\hline \multicolumn{1}{|c|}{ Issuer } & $\begin{array}{c}\text { Market } \\
\text { Capitalization } \\
\text { (in RSD) }\end{array}$ & Share \\
\hline NIS a.d., Novi Sad & $145,286,816,400$ & $20.87 \%$ \\
\hline AIK banka a.d., Niš & $14,780,765,304$ & $15.67 \%$ \\
\hline Komercijalna banka a.d., Beograd & $14,370,361,500$ & $11.57 \%$ \\
\hline Energoprojekt holding a.d., Beograd & $7,979,843,160$ & $10.26 \%$ \\
\hline Aerodrom Nikola Tesla a.d., Beograd & $17,316,121,750$ & $7.58 \%$ \\
\hline Soja protein a.d., Bečej & $9,235,224,880$ & $7.30 \%$ \\
\hline Imlek a.d., Beograd & $26,041,726,800$ & $4.90 \%$ \\
\hline Metalac a.d., Gornji Milanovac & $2,450,040,000$ & $4.90 \%$ \\
\hline Galenika Fitofarmacija a.d., Zemun & $3,593,040,000$ & $4.60 \%$ \\
\hline Messer Tehnogas a.d., Beograd & $5,198,839,870$ & $2.56 \%$ \\
\hline Jedinstvo a.d., Sevojno & $1,447,415,250$ & $2.38 \%$ \\
\hline Alfa plam a.d., Vranje & $2,185,150,000$ & $1.88 \%$ \\
\hline Goša montaža a.d., Velika Plana & $771,007,652$ & $1.51 \%$ \\
\hline Veterinarski zavod Subotica a.d., Subotica & $1,789,282,320$ & $0.82 \%$ \\
\hline Source: Belgrade Stock Exchange: Market Basket of BELEX15 Index as of 21.01 .2014 & \\
\hline
\end{tabular}


Grafikon 1: Kretanje vrednosti indeksa BELEX15 u periodu od 14.02.2011 do 05.02.2014. godine

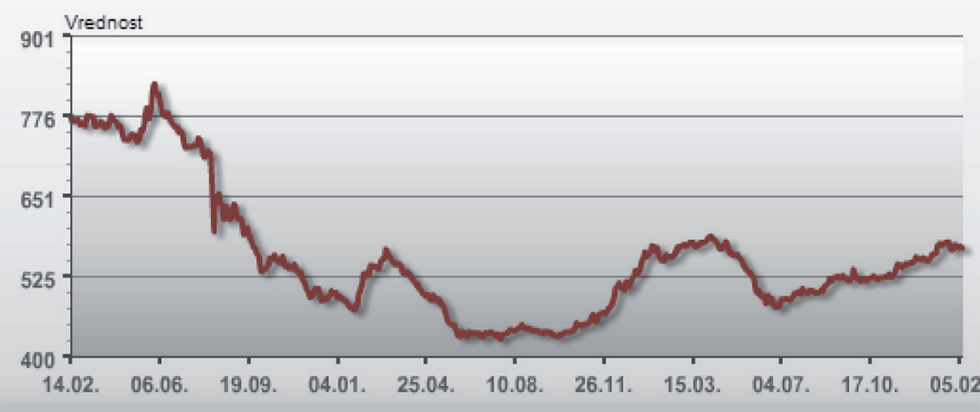

Izvor: Beogradska berza, 2014

instrumenata, slaba ponuda institucionalnih investitora, kao i zastoj u reformskim procesima penzijskog sistema, tržišta rada, fiskalnog sistema i brojni drugi faktori internog i eksternog karaktera.

\section{Zagrebačka berza (ZSE)}

Jedan od osnovnih zakona koji je Hrvatska morala da izmeni i prilagodi evropskim tržištima,

Imajući u vidu prethodno navedeno, može se konstatovati da iako je BELEX15 zabeležio rast $u$ trećem i četvrtom kvartalu 2013. godine, razloga za optimizam nema. Naime, brojni faktori stvaraju nepovoljnu investicionu klimu. Među njima su najvažniji: visok rizik zemlje, nedostatak poverenja investitora, nediversifikovanost finansijskih jeste Zakon o tržištu kapitala. Ovim zakonom uređeno je funkcionisanje redovnog tržišta, gde emitent mora da ispuni osnovne, minimalne uslove, dok je za ulazak na vodeće i službeno tržište nephodno ispuniti i dodatne uslove propisane Pravilnikom. Ova tri segmenta čine uređeno tržište (regulated market), na kome se trguje najlikvidnijim hartijama od vrednosti.

Slika 1: Organizacija tržišta ZSE

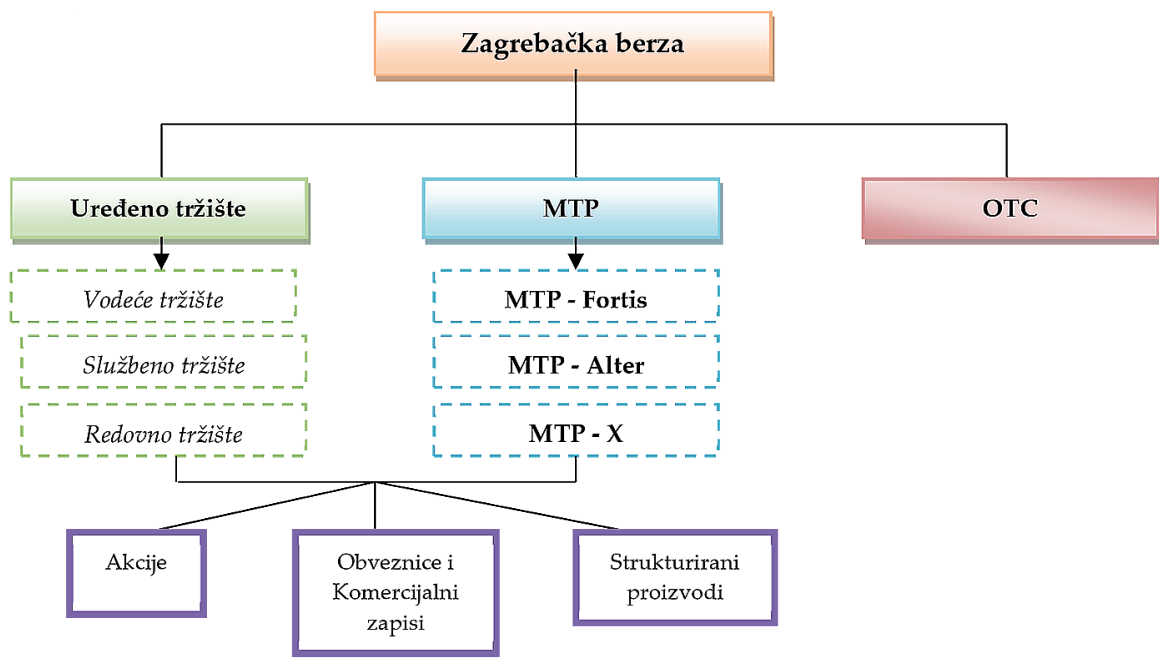

Izvor: Zagrebačka berza, 2014 
Graph 1 below illustrates the trends of BELEX15 in the period from 14.02.2011 to 05.02.2014. As can be seen, in the past three years it has recorded a drop by 200 index points. The highest value was reached on 06.06.2011, amounting to a total of 824.51 index points, and the lowest value on 25.07.2012, amounting to 426.8 index points. The decline of the BELEX15 Index value has been influenced by a large number of factors, the most important one, in addition to the global financial crisis, being the absence of IPOs in the privatization process. Low liquidity, high volatility and modest turnover are the characteristics of securities traded at the Belgrade Stock Exchange.

Graph 1: Trends of BELEX15 Index values in the period from 14.02.2011 to 05.02.2014

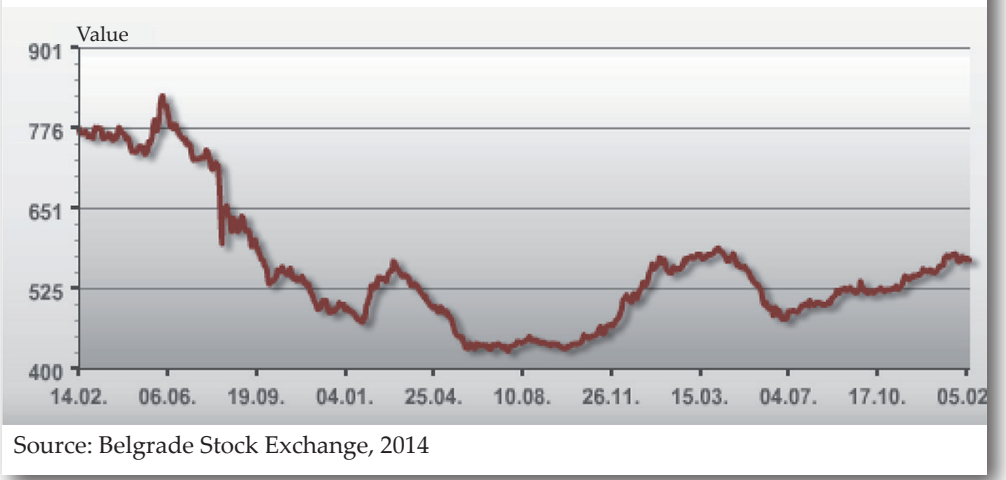

Bearing in mind the above stated, although the BELEX15 Index recorded a certain growth in the third and fourth quarter of 2013, there is no room for optimism. Namely, numerous factors have been generating an unfavorable investment climate. Most important among them include: high country risk, lack of trust on the part of investors, non-diversification of financial instruments, poor offer of institutional investors, and a delay in reform processes in the pension system, labor market, fiscal system, along with many other internal and external factors.

\section{Zagreb Stock Exchange (ZSE)}

One of the basic laws that Croatia was obliged to amend and adjust to the European markets was the Law on Capital Market. This Law regulates the functioning of the regular market, on which the issuer must meet the basic, minimum conditions, whereas in order to enter the prime and official markets the issuer must also meet additional conditions, as prescribed by the Rulebook. These three segments make up the regulated market, on which the most liquid securities are traded.

Figure 1: Organization of the ZSE market

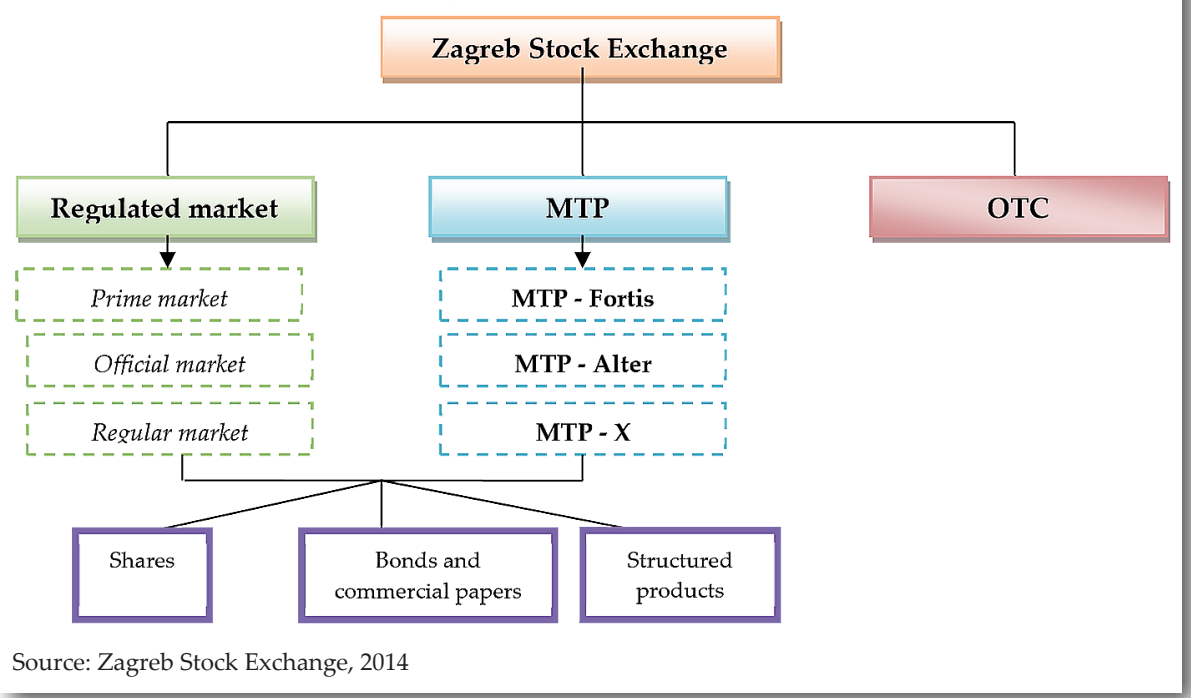


Na redovnom tržištu se trguje akcijama 155 emitenata, dok je na službenom tržištu 22 emitenta. Od obveznica se mogu izdvojiti: municipalne, korporativne i državne. Ono što ZSE izdvaja u odnosu na sve berze u regionu jeste raznovrsnost finansijskih instrumenta, kojima se trguje na uređenom tržištu i MTP-u. Pored akcija i obveznica trguje se i komercijalnim zapisima i strukturiranim proizvodima (Schmiedecke, 2008).

Podela na domaći i strani MTP zamenjena je MTP-om koji se deli na MTP - Alter, MTP - Fortis i MTP - X. MTP - Alter namenjen finansijskim instrumentima koji su deo nekog drugog uređenog tržišta u Hrvatskoj ili izvan nje. Fortis je namenjen instrumentima kojima se prvi put trguje, dok je MTP - X namenjen društvima u stečaju ili likvidaciji. Osnovni motiv ove podele je olakšanje postupaka prijema na tržište, kako bi kompanije neophodni kapital za rast i razvoj prikupili na berzi.

Na ovoj platformi trguje se akcijama i to samo na MTP-Fortis, koji broji 29 emitenata iz različitih privrednih sektora. Takođe, na MTF- Fortisu se trguje obveznicama Ministarstva finansija i Ministarstva za javne radove Republike Hrvatske. Na MTP-Alter tržištu se trguje strukturiranim proizvodima, gde se razlikuju sledeći turbo certifikati: EURO BUND FUTURE long, DAX long, ERSTE GROUP BANK (akcija) long, zlato long, srebro long, E-mini S\&P 500 long, WTI light sweet (nafta) short (Pečarić, Arnerić, Radić, 2012: 113).

Prelomna tačka u razvoju Zagrebačke berze bilo je donošenje Zakona o tržištu hartija od vrednosti koji je stupio na snagu 25. jula 2002. godine. Stroge odredbe toga zakona su "prisilile" veliki broj akcionarskih društava da "izađu" (going-public) na berzu, tj. da ispune uslove za kotiranje u nekoj od kotacija berze (Jakšić, 2007: 332). Zakon iz 2002. godine je zamenjen 2008. godine Zakonom o tržištu kapitala (NN 88/08).

Poslove društva vodi Uprava društva, koja se sastoji od dva člana i zastupaju društvo samostalnoi pojedinačno. Nadzorni odborizmeđu imenovanih članova određuje predsednika Uprave, a način njihovog funkcionisanja donosi Uprava uz saglasnost Nadzornog odbora (Statut Zagrebačke berze, član 7).

Na Zagrebačkoj berzi se razlikuje 8 indeksa, čiju korpu čine akcije, kao i 2 indeksa koja pokazuju kretanje vrednosti obveznica na ZSE. Pored CROBEX i CROBEX10 indeksa, razlikuje se i CROBEXindustrija, CROBEXkonstrikt, CROBEXnutris,

CROBEXplus, CROBEXtranspor i CROBEXturist. Takođe, tržište koje je na ZSE u velikom usponu, tržište obveznica, ima dva pokazatelja i to CROBIS i CROBISTR. CROBEX je službeni akcijski indeks Zagrebačke berze i prvi put je objavljen septembra 1997. godine sa baznom vrednošću od 1.000 bodova (Jakšić, 2007: 334). CROBEX se karakteriše po tome što korpu ovog indeksa čine samo akcije kojima se trguje na uređenom tržištu i kojima se trgovalo više od 90\% ukupnog broja trgovinskih dana $\mathrm{u}$ polugodišnjem periodu (Faruk, Huljak, 2004: 83). Rang svake akcije, koja ispunjava prethodno naveden uslov, određuje se na osnovu dva kriterijuma:

1. udeo u free float tržišnoj kapitalizaciji i

2. udeo u prometu ostvarenom unutar knjige ponuda u polugodišnjem periodu.

U sastav indeksa CROBEX ulazi 25 akcija sa najvećim prosekom po osnovu oba kriterijuma. Kako bi se izdvojile najlikvidnije (blue chip) akcije na berzi, formiran je indeks CROBEX10, koga čine kompanije sa najvećom free float tržišnom kapitalizacijom i prometom. Vrednost indeksa se izračunava prema sledećoj formuli:

$$
I_{t}^{J}=\frac{\sum_{i=1}^{n} p_{i, t}^{j} * q_{i, r} * f_{i, r}}{K_{t} * \sum_{i=1}^{n} p_{i, r} * q_{i, r} * f_{i, r}} * B
$$

pri čemu su:

$\mathrm{I}_{\mathrm{t}}^{\mathrm{j}}$ - vrednost indeksa CROBEX10 na dan $t \mathrm{i}$ vreme $j$,

$\mathrm{p}_{\mathrm{i}, \mathrm{t}}{ }^{\mathrm{j}}$ - zadnja cena akcija na dan $t$ i vreme $j$,

$\mathrm{q}_{\mathrm{i}, \mathrm{T}}$ - broj emitovanih akcija na dan revizije $\mathrm{T}$,

$\mathrm{f}_{\mathrm{i}, \mathrm{T}}$ - free float faktor akcija zadnjeg dana $\mathrm{u}$ mesecu koji prethodi danu revizije $\mathrm{T}$,

B - bazna vrednost indeksa, iznosila je 1000 na dan 31. 07. 2009. god.,

$\mathrm{p}_{\mathrm{i}, \mathrm{T}-}$ zadnja cena akcija na bazni datum ili na dan koji prethodi uključenju u indeks,

KT - koeficijent prilagođavanja baze indeksa na dan revizije $\mathrm{T}$. 
Trading at the regular market involves the shares of 155 issuers, and the official market the shares of 22 issuers. Traded bonds include: municipal, corporate and government bonds. What sets the ZSE apart from all other stock exchanges in the region is the diversity of financial instruments, traded on the regulated market and MTP. Apart from shares and bonds, the Stock Exchange also trades in commercial papers and structured products (Schmiedecke, 2008).

The division into domestic and foreign MTP has been replaces by the MTP divided into: MTP-Alter, MTP-Fortis and MTP-X. MTP-Alter is targeted at financial instruments which are part of some other regulated market in Croatia or beyond. Fortis is targeted at instruments traded for the first time, whereas MTP-X is for bankrupt or liquidated companies. The basic idea behind this division is to simplify the procedure of entering the market, so that the companies could more easily access the stock exchange to raise capital required for growth and development.

At this platform only shares are traded, exclusively on MTP-Fortis, which gathers 29 issuers from various economic sectors. Moreover, MTF-Fortis trades in bonds of the Ministry of Finance and Ministry of Public Administration of the Republic of Croatia. MTP-Alter market trades in structured products, with the following turbo certificates: EURO BUND FUTURE long, DAX long, ERSTE GROUP BANK (share) long, gold long, silver long, E-mini S\&P 500 long, WTI light sweet (oil) short (Pečarić, Arnerić, Radić, 2012: 113).

The turning point in the development of Zagreb Stock Exchange was the adoption of the Law on Securities, which came into effect on 25 July 2002. The rigid provisions of that Law "forced" a large number of shareholding companies to go public, i.e. to meet the conditions to be quoted in some of the stock exchange quotes (Jakšić, 2007: 332). The 2002 Law was substituted by the Law on Capital Market in 2008 (NN 88/08).

The Management Board consisting of two members manages the Company's business affairs, in an individual and several capacity. The Supervisory Board appoints one member to be the Management Board President, and the functioning of the Management Board is defined by the Management Board subject to the approval of the Supervisory Board (Statute of the Zagreb Stock Exchange, Article 7).

At the Zagreb Stock Exchange there are 8 indices, whose baskets contain shares, and 2 indices indicating the trends in the value of bonds traded at the ZSE. In addition to CROBEX and CROBEX10 indices, the indices are: CROBEXindustrija, CROBEXkonstrikt, CROBEXnutris, CROBEXplus, CROBEXtranspor and CROBEXturist. Moreover, the booming ZSE bond market has two indices: CROBIS and CROBISTR. CROBEX is the official share index of the Zagreb Stock Exchange, first published in September 1997, with the basic value of 1,000 points (Jakšić, 2007: 334). CROBEX is characteristic because its basket contains only shares traded at the regulated market, and on more than $90 \%$ of the available trading days in the previous six-month period (Faruk, Huljak, 2004: 83). The ranking of each share, meeting the previously stated condition, is determined based on two criteria:

1. Share in free float market capitalization; and

2. Share in order book turnover within six months.

CROBEX Index includes 25 shares with the highest average in respect of both criteria. In order to separate blue chips at the stock exchange, CROBEX10 Index was formed, including companies with the highest free float market capitalization and turnover. The value of this index is calculated according to the following formula

$$
I_{t}^{J}=\frac{\sum_{i=1}^{n} p_{i, t}^{j} * q_{i, r} * f_{i, r}}{K_{t} * \sum_{i=1}^{n} p_{i, r} * q_{i, r} * f_{i, r}} * B
$$

where:

$I_{t}^{j}$ - value of CROBEX10 Index on day $t$ and time $j$,

$\mathrm{p}_{\mathrm{i}, \mathrm{t}}^{\mathrm{j}}$ - final share price on day $t$ and time $j$,

$\mathrm{q}_{\mathrm{i}, \mathrm{T}}$ - number of shares issued on revision day $\mathrm{T}$, $f_{i, T}$ - free float factor of shares on the last day of the month preceding the revision day $\mathrm{T}$,

B - base index value, equaling 1000 as of 31.07.2009,

$\mathrm{p}_{\mathrm{i}, \mathrm{T}}$ - final price of shares on the base date or any other date preceding their inclusion into the index,

$\mathrm{KT}$ - index base adjustment factor on revision day $\mathrm{T}$. 
Tabela 2: Korpa indeksa CROBEX10

\begin{tabular}{|l|r|r|}
\hline Izdavalac & \multicolumn{1}{c|}{$\begin{array}{c}\text { Tržišna } \\
\text { kapitalizacija }\end{array}$} & $\begin{array}{r}\text { Udeo u } \\
\text { indeksu }\end{array}$ \\
\hline Adris grupa d.d. (ADRS-P-A) & $1.196 .610 .902,37$ & $10,38 \%$ \\
\hline Atlantic Grupa d.d. (ATGR-R-A) & $741.214 .890,00$ & $6,43 \%$ \\
\hline Ericsson Nikola Tesla d.d. (ERNT-R-A) & $1.113 .260 .160,00$ & $9,66 \%$ \\
\hline HT d. d. (HT-R-A) & $1.117 .986 .402,50$ & $9,7 \%$ \\
\hline INA d. d. (INA-R-A) & $931.270 .905,00$ & $8,08 \%$ \\
\hline Končar - elektroindustrija d.d. (KOEI-R-A) & $1.131 .811 .115,00$ & $9,82 \%$ \\
\hline Valamar Adria Holding d. d. (KORF-R-A) & $577.930 .429,44$ & $5,01 \%$ \\
\hline Ledo d.d. (LEDO-R-A) & $1.207 .807 .200,00$ & $10,48 \%$ \\
\hline Podravka d.d. (PODR-R-A) & $1.043 .350 .550,00$ & $9,05 \%$ \\
\hline Petrokemija d.d. (PTKM-R-A) & $243.550 .796,61$ & $2,11 \%$ \\
\hline
\end{tabular}

Izvor: Zagrebačka berza: Korpa indeksa CROBEX10 na dan 21.1.2014.

Grafikon 2: Kretanje indeksa CROBEX10, u periodu od 11.02.2011. do 11.02.2014. godine

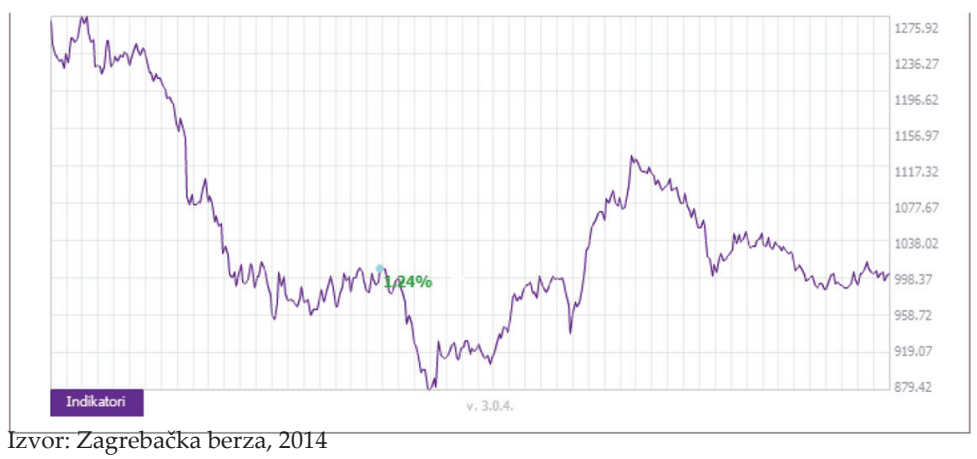

Imajući u vidu navedeno, može se zaključiti da je trend BELEX15 indeksa i CROBEX10 indeksa, u posmatranom vremenskom periodu od tri godine, sličan. Naime, najveću i najnižu vrednost oba indeksa su zabeležila $\mathrm{u}$ istim kvartalima 2011. godine, odnosno 2012. godine. CROBEX10 je dostigao najvišu vrednost 22.04.2011. godine od ukupno 1240 indeksnih poena, a najnižu vrednost 20.06.2012. godine od ukupno 880 indeksnih poena. Međutim, potrebno je naglasiti da Zagrebačka berza u odnosu na druge berze zemalja bivše Jugoslavije ima vodeću poziciju kako po obimu prometa, tako i po tržišnoj kapitalizaciji. Ukupan promet na Zagrabačkoj berzi u 2012. godini je iznosio 511,1 mil. evra, dok je ukupan promet $\mathrm{u}$ istom periodu na Beogradskoj berzi iznosio 220 mil. evra, S druge strane tržišna kapitalizacija Zagrabačke berze u 2012. godini je iznosila 25,4 mlrd. evra, dok je isti pokazatelj na Beogradskoj berzi bio 5,7 mlrd. evra (Godišnji izveštaji berzi, 2012).

\section{Varšavska berza}

Varšavska berza je primer berze sa raznovrsnim finansijskim instrumentima, koji pružaju mogućnost investitorima da konstruišu različite portfolije. Finansijski instrumenti listirani na WSE su podeljeni $u$ tri grupe:

hartije od vrednosti akcije, obveznice, strukturirane obveznice, strukturirani proizvodi (certifikati),

- $\quad$ izvedene hartije od vrednosti - prvo su na tržište uvedeni fjučers ugovori na indekse $\mathrm{i}$ to za indeks WIG20, zatim opcije i varanti i

- ostali finansijski instrumenti - ugovori kratke prodaje i strukturiranih proizvoda, koje predstavljaju posebne izvedene hartije od vrednosti.

KaoinaBSEtrgujeseu sistemu kontinuiranog trgovanja ili u sistemu jedne cene sa dve aukcije. Transakcije se izvršavaju elektronski, preko informacionog sistema Berze. Nacionalni depo za hartije od vrednosti obavlja poslove sa hartijama od vrednosti: isplate dividendi, podelu akcija i otkup obveznica. Transakcije se izvršavaju u T +3 ciklusu, odnosno trećeg dana nakon zaključivanja transakcije.

Aprila 2013. godine implementirana je Univerzalna trgovačka platforma (UTP), koja predstavlja prekretnicu u tehnološkom napretku WSE. U odnosu na Varset, UTP je mnogo brži, efikasniji i obezbeđuje organizaciju trgovanja u skladu sa svetskim trendovima i rastućim zahtevima učesnika na tržištu. Ulaskom $\mathrm{u}$ grupu berza koje već koriste UTP (Njujork, Pariz, Lisabon i Amsterdam), WSE postaje deo 
Table 2: CROBEX10 Index Basket

\begin{tabular}{|l|r|r|}
\hline Issuer & $\begin{array}{c}\text { Market } \\
\text { Capitalization }\end{array}$ & $\begin{array}{c}\text { Index } \\
\text { share }\end{array}$ \\
\hline Adris grupa d.d. (ADRS-P-A) & $1,196,610,902.37$ & $10.38 \%$ \\
\hline Atlantic Grupa d.d. (ATGR-R-A) & $741,214,890.00$ & $6.43 \%$ \\
\hline Ericsson Nikola Tesla d.d. (ERNT-R-A) & $1,113,260,160.00$ & $9.66 \%$ \\
\hline HT d. d. (HT-R-A) & $1,117,986,402.50$ & $9.7 \%$ \\
\hline INA d. d. (INA-R-A) & $931,270,905.00$ & $8.08 \%$ \\
\hline Končar - elektroindustrija d.d. (KOEI-R-A) & $1,131,811,115.00$ & $9.82 \%$ \\
\hline Valamar Adria Holding d. d. (KORF-R-A) & $577,930,429.44$ & $5.01 \%$ \\
\hline Ledo d.d. (LEDO-R-A) & $1,207,807,200.00$ & $10.48 \%$ \\
\hline Podravka d.d. (PODR-R-A) & $1,043,350,550.00$ & $9.05 \%$ \\
\hline Petrokemija d.d. (PTKM-R-A) & $243,550,796.61$ & $2.11 \%$ \\
\hline Source: Zagreb Stock Exchange: CROBEX10 Index Basket as of 21.1.2014 & \\
\hline
\end{tabular}

capitalization of the Zagreb Stock Exchange in 2012 amounted to 25.4 billion EUR, whereas the same indicator at the Belgrade Stock Exchange amounted to 5.7 billion EUR (Annual Reports of the concerned stock exchanges, 2012).

\section{Warsaw Stock Exchange}

The Warsaw Stock Exchange is an example of a stock exchange with diverse financial instruments, granting
Graph 2: CROBEX10 Index, in the period from 11.02.2011 to 11.02 .2014

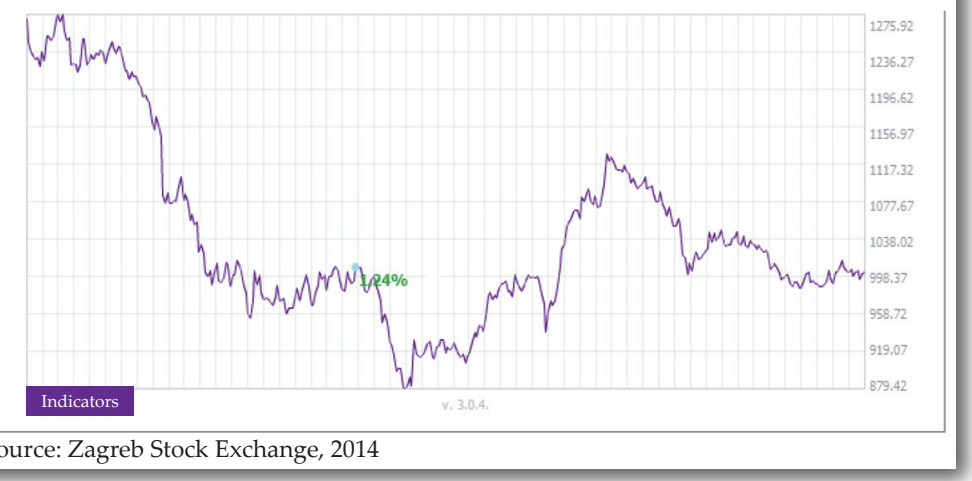

the investors an opportunity to construct different portfolios. Financial instruments listed on the WSE are divided into three groups:

- Securities - shares, bonds, structured bonds, structured products (certificates);

- Derivatives - futures on indices, in particular on WIG20 Index, were the first ones introduced into the market, followed by options and warrants; and

- Other financial instruments - short sale and structured products contracts, representing special derivatives.

Just like at the BSE, the trading is conducted according to the continuous trading method or within a single price system with two auctions. Transactions are performed electronically, via the Stock Exchange's IT system. The National Securities depository conducts securitiesrelated operations: disbursement of dividends, distribution of shares and purchase of bonds. Transactions are performed in a $\mathrm{T}+3$ cycle, i.e. on the third day upon concluding a transaction.

In April 2013 the WSE implemented the Universal Trading Platform (UTP), marking a turning point in its technological development. Compared to Varset, UTP is much faster and more efficient, enabling the organization of trading to be in line with the worldwide 
mreže najnaprednijih globalnih tržišta kapitala. O tome govori i struktura investitora prikazana na sledećem grafikonu, gde se može uočiti stalni rast stranih i institucionalnih investitora u periodu od 2005 -2011. godine. zavisnosti od visine tržišne kapitalizacije, u jedan od četiri segmenta: MINUS 5, 5 PLUS, 50 PLUS ili 250 PLUS. Kapitalizacija kompanije se izračunava kao aritmetička sredina njihove kapitalizacije za poslednja tri meseca (Varšavska berza, 2013):

\section{Grafikon 3: Struktura investitora na WSE}

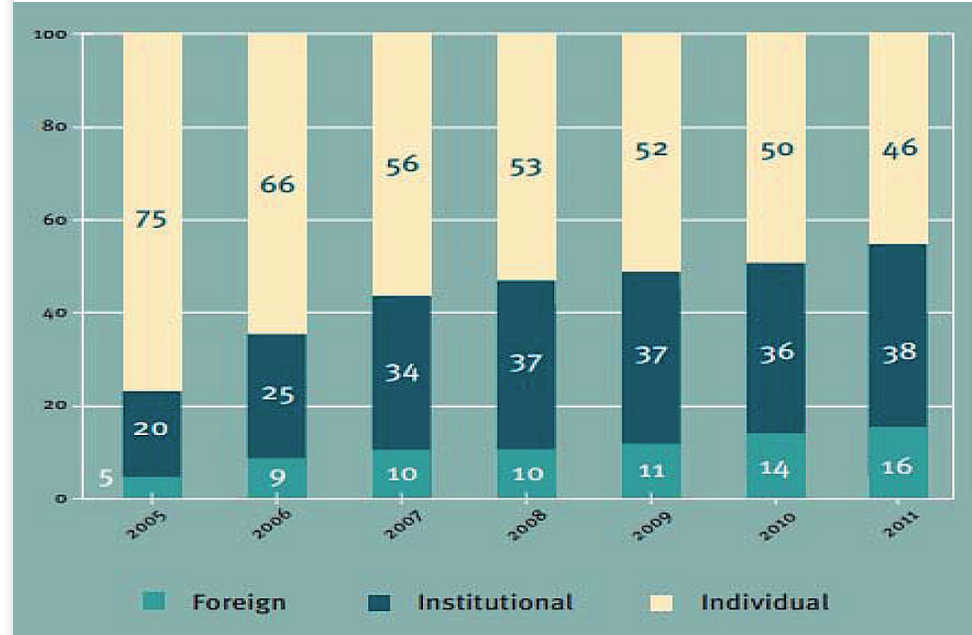

Izvor: Varšavska berza, 2012
- MINUS 5 segment obuhvata akcije kompanija sa kapitalizacijom do 5 miliona evra; - Segment 5 PLUS uključuje akcije kompanija sa kapitalizacijom od 5 miliona evra do 50;

- Segment 50 PLUS uključuje akcije kompanija sa kapitalizacijom od 50 miliona evra do 250 miliona;

- Segment 250 PLUS uključuje akcije kompanija sa kapitalizacijom preko 250 miliona evra.

Varšavska berza posluje na osnovu zakonskih akata donetih

Akcije svih listiranih kompanija na u julu 2005. godine. regulisanom tržištu su klasifikovane, u

Slika 2: Najvažniji organi upravljanja i supervizije na WSE

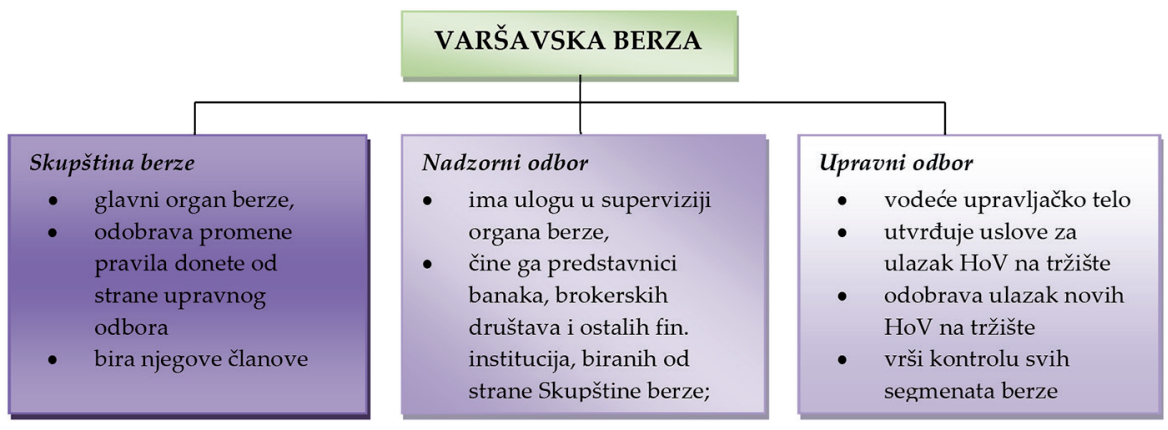

Izvor: Chuda, et al., 2012 
trends and the growing demands of market participants. Having joined the group of stock exchanges already using UTP (New York, Paris, Lisbon and Amsterdam), the WSE became a part of the network gathering the most advanced global capital markets. What confirms this is the structure of investors shown on the graph below, indicating a permanent growth of foreign and institutional investors in the period 2005-2011.

The shares of all listed companies on the regulated market are classified, depending on the amount of market capitalization, into one of the following four segments: MINUS 5, 5 PLUS, 50 PLUS or 250 PLUS. A company's capitalization is calculated as the arithmetic mean of its capitalization in the last three months (Warsaw Stock Exchange, 2013):

- MINUS 5 segment includes shares of companies with capitalization up to 5 million euros;

Graph 3: Structure of investors at the WSE

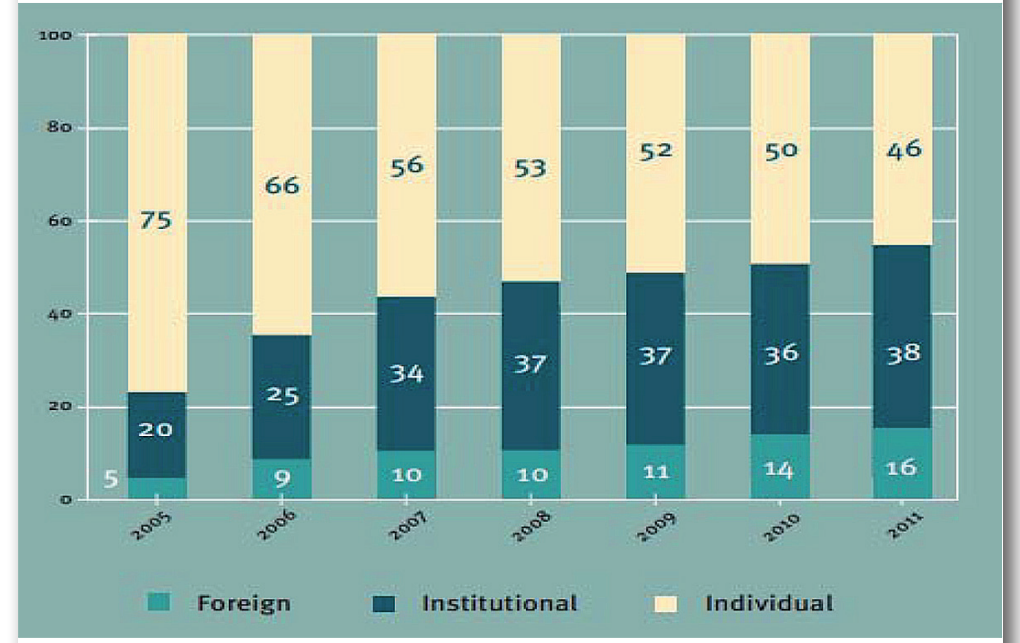

Source: Warsaw Stock Exchange, 2012
- 5 PLUS segment includes shares of companies with capitalization from 5 to 50 million euros;

- 50 PLUS segment includes shares of companies with capitalization from 50 to 250 million euros;

- 250 PLUS segment includes shares of companies with capitalization over 250 million euros.

The Warsaw Stock Exchange operates pursuant to the legal bylaws adopted in July 2005.

Figure 2: Major management and supervision bodies at the WSE

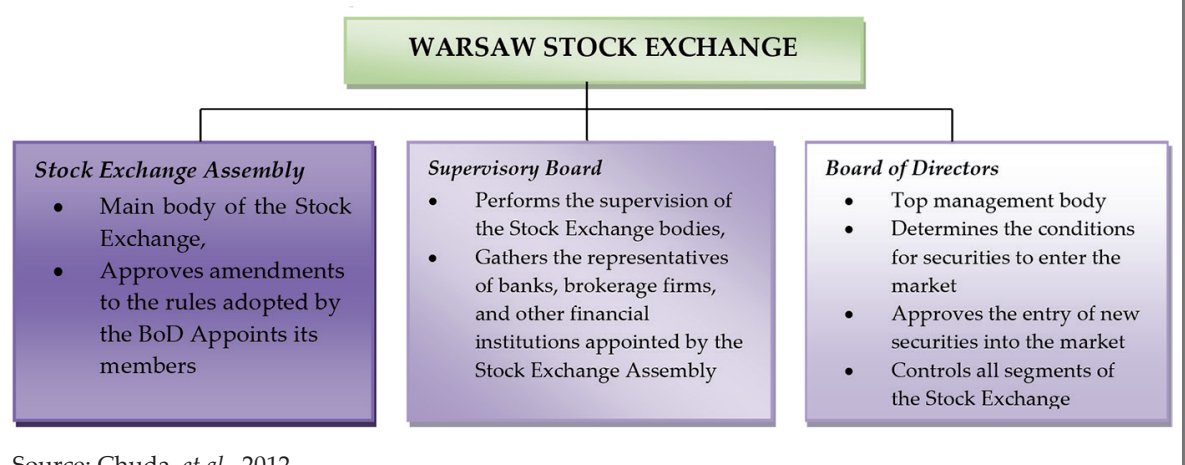

Source: Chuda, et al., 2012 
Članovi Berze ne pripadaju organizacionoj strukturi WSE, ali bez njihovog prisustva na tržištu trgovanje ne bi bilo moguće. U skladu sa Pravilnikom Berze razlikuju se tri grupe članova Berze (Varšavska berza, 2013):

- investicione kompanije koje se bave poslovima za sopstveni račun ili za račun svojih klijenata;

- članovi Nacionalnog depoa za hartije od vrednosti, koji zaključuju transakcije isključivo za sopstveni račun;

- kao i drugi subjekti, koji zaključuju transakcije po pravilima Nacionalnog depoa za hartije od vrednosti.

Od 2004. godine banke su takođe ovlašćene da postanu članovi Berze. One rade za sopstveni račun bez potrebe posedovanja posebnog odeljenja za brokere (Proniewski, Niedzwiecki, 2009: 106).

Na Varšavskoj berzi se razlikuju 24 različita indeksa, pri čemu se vrednosti indeksa WIG20, WIG20short, WIG20lev, mWIG40, sWIG80, WIG-Plus, WIGdiv, RESPECT WIGCEE prikazuju tokom procesa kontinuiranog trgovanja, dok WIG20TR, WIG-Polski, WIGUkrajinski i sektorski podindeksi:WIG-banking, WIG-basic materials, WIG-construction, WIGchemical, WIG-developers, WIG-energy, WIGIT, WIG-media, WIG-oil\&gas, WIG-food, WIGtelecomindices se publikuju između tri sesije.

Vrednost indeksa WIG30 (WIG20+10 najlikvidnijih kompanija na listi) se obračunava na osnovu vrednosti portfelja 30 najlikvidnijih kompanija (blue chips) na WSE glavnoj listi. Baza vrednost indeksa WIG30 postavljena na nivou od
2582.98 poena. WIG30 ne može da sadrži više od 7 kompanija iz jedne oblasti, a njihovo učešće je ograničeno na $10 \%$. Postoje dva osnovna načina izračunavanja vrednosti indeksa, čiju korpu čine akcije kojima se trguje na kontinuiranom tržištu (WIG30), a to su (Varšavska berza, 2013):

INDEX WIG30 $=\frac{\text { Trenutna kapitalizacija }}{\text { Bazna kapitalizacija } * \text { prilagođavajući faktor }} *$ bazna vrednost indeksa

ili:

$$
\text { INDEX WIG30 }=\frac{\sum \mathrm{P}_{(\mathrm{i})} * \mathrm{~S}_{(\mathrm{i})}}{\sum \mathrm{P}_{(0)} * \mathrm{~S}_{(0)} * \mathrm{~K}_{(\mathrm{t})}} * \mathrm{I}_{(0)}
$$

gde su:

S(i) - ponderisani indeks $i$ učesnika tokom određene sesije

$\mathrm{P}(\mathrm{i})$ - vrednost indeksa $i$ učesnika tokom određene sesije

$\mathrm{S}(0)$ - ponderisani indeks $i$ učesnika tokom određene sesije $u$ baznom periodu

$\mathrm{P}(0)$ - vrednost indeksa $i$ učesnika tokom određene sesije $u$ baznom periodu

$\mathrm{K}(\mathrm{t})$ - indeks faktora prilagođavanja tokom određene sesije

$\mathrm{I}(0)$ - osnovna vrednost indeksa:

- za WIG30 osnovna vrednost indeksa iznosila je 2582,98 poena

- na dan 21.1.2014. godine vrednost WIG30 je 2504,83 poena

Za WIG30, WIG30TR, WIG20, WIG20TR, mWIG40 i sWIG80 razvijen je sistem rangiranja na osnovu postignutih poena izabranih kompanija. Rang se izračunava prema sledećoj formuli (Varšavska berza, 2013):

Tabela 3: Deset najlikvidnijih kompanija indeksa WIG30

\begin{tabular}{|l|r|r|}
\hline Izdavalac & $\begin{array}{c}\text { Tržišna } \\
\text { kapitalizacija } \\
\text { (PLN u } \\
\text { milionima) }\end{array}$ & $\begin{array}{c}\text { Učešće u } \\
\text { indeksu } \\
\text { WIG30 }\end{array}$ \\
\hline Bank polska kasa opieki spółka akcyjna (PKOBP) & $19.563,21$ & $10,05 \%$ \\
\hline Powszechna kasa oszczędności bank polski spółka akcyjna (PEKAO) & $18.925,44$ & $9,96 \%$ \\
\hline Powszechny zakład ubezpieczeń spółka akcyjna (PZU) & $18.014,39$ & $9,76 \%$ \\
\hline Polski koncern naftowy orlen spółka akcyjna (PKN) & $13.469,46$ & $6,95 \%$ \\
\hline Kghm polska miedź spółka akcyjna (KGH) & $13.299,65$ & $8,27 \%$ \\
\hline Pge polska grupa energetyczna spółka akcyjna (PGE) & $10.867,70$ & $6,28 \%$ \\
\hline Polskie górnictwo naftowe i gazownictwo spółka akcyjna (PGN) & $9.980,80$ & $4,35 \%$ \\
\hline Bank zachodni wbk spółka akcyjna (BZV) & $8.798,06$ & $5,69 \%$ \\
\hline Lpp spółka akcyjna (LPP) & $6.547,20$ & $4,36 \%$ \\
\hline Mbank spółka akcyjna (MBK) & $5.409,75$ & $3,38 \%$ \\
\hline
\end{tabular}


Members of the Stock Exchange are not part of the WSE organizational structure, but without their presence on the market trading would be impossible. According to the Stock Exchange Rulebook, there are three groups of Stock Exchange members (Warsaw Stock Exchange, 2013):

- Investment companies conducting operations for their own account or on behalf of their clients;

- Members of the National Securities Depository, concluding transactions exclusively for their own account;

- Other entities, concluding transactions pursuant to the rules of the National Securities Depository.

Since 2004 banks have also been authorized to become Stock Exchange members. They operate for their own account, with no required separate brokerage department (Proniewski, Niedzwiecki, 2009: 106).

The Warsaw Stock Exchange has 24 different indices, with the values of the indices WIG20, WIG20short, WIG20lev, mWIG40, sWIG80, WIG-Plus, WIGdiv, RESPECT WIG-CEE being shown during the continuous trading process, whereas the indices WIG20TR, WIG-Polski, WIG-Ukrajinski, and sectorial sub-indices: WIG-banking, WIG-basic materials, WIGconstruction, WIG-chemical, WIG-developers, WIG-energy, WIG-IT, WIG-media, WIGoil\&gas, WIG-food, WIG-telecom indices get published in between the three sessions.

The value of WIG30 Index (WIG20+10 top liquid companies on the list) is calculated based on the value of the portfolio including 30 top liquid companies (blue chips) on the WSE main list. The base value of WIG30 Index is set to the level of 2582.98 points. WIG30 cannot include more than 7 companies from a single field, and their participation is limited to $10 \%$. There are two basic ways to calculate the value of an index whose basket contains shares traded on the continuous market (WIG30), as follows (Warsaw Stock Exchange, 2013):

$$
\begin{aligned}
& \text { INDEX WIG } 30=\frac{\text { Current capitalization }}{\text { Base capitalization } * \text { adjustment factor }} * \text { base index value } \\
& \text { Or: } \\
& \text { INDEX WIG30 }=\frac{\sum \mathrm{P}_{(\mathrm{i})} * \mathrm{~S}_{(\mathrm{i})}}{\sum \mathrm{P}_{(0)} * \mathrm{~S}_{(0)} * \mathrm{~K}_{(\mathrm{t})}} * \mathrm{I}_{(0)}
\end{aligned}
$$

with:

S(i) - weighted index of the participant $i$ during a certain session

$\mathrm{P}(\mathrm{i})$ - index value of the participant $i$ during a certain session

$S(0)$ - weighted index of the participant $i$ during a certain session in the base period

$\mathrm{P}(0)$ - index value of the participant $i$ during a certain session in the base period

$\mathrm{K}(\mathrm{t})$ - adjustment factor index during a certain session

$\mathrm{I}(0)$ - base index value:

- Base value of the WIG30 index amounted to 2582,98 points

- As on 21.1.2014 the value of the WIG30 index is 2504,83 points

For WIG30, WIG30TR, WIG20, WIG20TR, mWIG40 and sWIG80 indices the WSE developed a system of ranking based on the points achieved by select companies. The ranking is calculated according to the following formula (Warsaw Stock Exchange, 2013): 


$$
\mathrm{R}(\mathrm{i})=0.6 * \mathrm{sT}(\mathrm{i})+0.4 * \mathrm{sC}(\mathrm{i})
$$

gde su:

$\mathrm{R}(\mathrm{i})$ - rejting poeni ostvareni od strane $i$ kompanije

sT(i) - akcije $i$ kompanije u ukupnom prometu u poslednjih 12 meseci

sC(i) - vrednost akcija $i$ kompanije u slobodnom prometu na dan izračunavanja rejtinga (ranga)

Grafikon 4: Kretanje WIG30 za period 11.2.2011-11.2.2014.

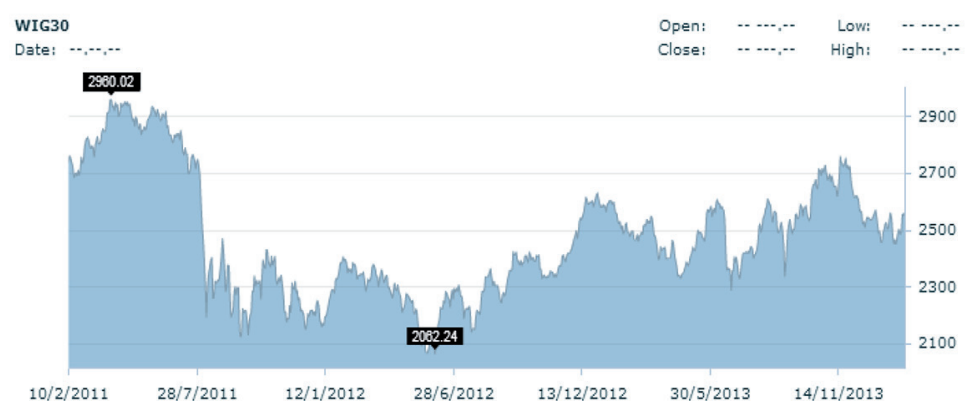

Izvor: Varšavska berza, 2014

Imajući u vidu Grafik 4, može se konstatovati da je WIG30 dostigao najvišu vrednost 1.4.2011. godine od ukupno 2960,2 indeksna poena, dok je najniža vrednost dostignuta 1.6.2012. godine od ukupno 2062,04 indeksnih poena.
U poređenju sa predstavljenim indeksima Beogradske i Zagrebačke berze uočava se sličan trend kretanja sva tri indeksa, u pogledu dostizanja maksimalnih i minimalnih vrednosti.

\section{Uporedna analiza poslovanja posmatranih berzi}

Veličina srpskog tržišta kapitala $\mathrm{u}$ odnosu na zemlje $\mathrm{u}$ regionu biće pozicionirana $\mathrm{uz}$ pomoć market capitalization ratio. Preciznije, ovaj pokazatelj je jednak ukupnoj tržišnoj vrednosti listiranih akcija podeljenoj bruto domaćim proizvodom (MC) GDP). Iako velika tržišta nužno ne funkcionišu efikasno, u literaturi se vrlo često ovaj racio koristi kao pokazatelj razvoja tržišta akcija, pod pretpostavkom da je veličina berze u pozitivnoj korelaciji sa mogućnošću mobilizacije kapitala i diversifikacije rizika (Levine and Zervos, 1998). U Tabeli 4 prikazan je market capitalization ratio posmatranih zemalja u regionu.

Tabela 4: Uporedni pregled veličine tržišta kapitala zemalja u regionu u periodu od 2005. do 2012. godine (\% od GDP)

\begin{tabular}{|c|c|c|c|c|c|c|c|c|}
\hline Zemlja & 2005 & 2006 & 2007 & 2008 & 2009 & 2010 & 2011 & 2012 \\
\hline Bugarska & 17,60 & 31,09 & 51,75 & 17,09 & 14,63 & 15,25 & 15,42 & 13,08 \\
\hline Hrvatska & 28,82 & 58,18 & 111,19 & 38,32 & 40,41 & 40,94 & 34,14 & 36,4 \\
\hline Mađarska & 29,53 & 37,26 & 35,01 & 12,05 & 22,34 & 21,54 & 13,41 & 16,92 \\
\hline Makedonija & 10,79 & 16,74 & 33,28 & 8,37 & 9,90 & 6,96 & 5,56 & 5,82 \\
\hline Crna Gora & 46,46 & 65,04 & 100,82 & 63,34 & 103,57 & 87,67 & 73,00 & 87,5 \\
\hline Srbija & 21,43 & 37,59 & 61,44 & 25,47 & 28,70 & 25,22 & 18,57 & 19,87 \\
\hline Poljska & 30,89 & 43,63 & 48,74 & 17,14 & 31,4 & 40,49 & 26,81 & 36,27 \\
\hline Slovenija & 22,11 & 38,98 & 61,22 & 21,56 & 23,99 & 20,10 & 12,59 & 14,30 \\
\hline
\end{tabular}

Izvor: The World Bank 


Table 3: Top ten most liquid companies according to the WIG30 Index
\begin{tabular}{|l|r|r|}
\hline Issuer & $\begin{array}{c}\text { Market } \\
\text { Capitalization } \\
\text { (PLN in } \\
\text { million) }\end{array}$ & $\begin{array}{c}\text { WIG30 } \\
\text { Index } \\
\text { share }\end{array}$ \\
\hline Bank polska kasa opieki spółka akcyjna (PKOBP) & $19,563.21$ & $10.05 \%$ \\
\hline Powszechna kasa oszczędności bank polski spółka akcyjna (PEKAO) & $18,925.44$ & $9.96 \%$ \\
\hline Powszechny zakład ubezpieczeń spółka akcyjna (PZU) & $18,014.39$ & $9.76 \%$ \\
\hline Polski koncern naftowy orlen spółka akcyjna (PKN) & $13,469.46$ & $6.95 \%$ \\
\hline Kghm polska miedź spółka akcyjna (KGH) & $13,299.65$ & $8.27 \%$ \\
\hline Pge polska grupa energetyczna spółka akcyjna (PGE) & $10,867.70$ & $6.28 \%$ \\
\hline Polskie górnictwo naftowe i gazownictwo spółka akcyjna (PGN) & $9,980.80$ & $4.35 \%$ \\
\hline Bank zachodni wbk spółka akcyjna (BZV) & $8,798.06$ & $5.69 \%$ \\
\hline Lpp spółka akcyjna (LPP) & $6,547.20$ & $4.36 \%$ \\
\hline Mbank spółka akcyjna (MBK) & $5,409.75$ & $3.38 \%$ \\
\hline Source: Warsaw Stock Exchange. WIG 30 Index Basketas of 21.12014 & & \begin{tabular}{c} 
I. \\
\hline
\end{tabular}
\end{tabular}

Source: Warsaw Stock Exchange. WIG 30 Index Basket as of 21.1.2014

with:

$$
\mathrm{R}(\mathrm{i})=0.6 * \mathrm{sT}(\mathrm{i})+0.4 * \mathrm{sC}(\mathrm{i})
$$

$\mathrm{R}(\mathrm{i})$ - rating points achieved by the company $i$ $\mathrm{sT}(\mathrm{i})$ - shares of the company $i$ in total turnover in the last 12 months

$\mathrm{sC}(\mathrm{i})$ - value of shares of the company $i$ in free turnover on the day of rating calculation

Graph 4: Trends of WIG30 Index in the period 11.2.201111.2.2014

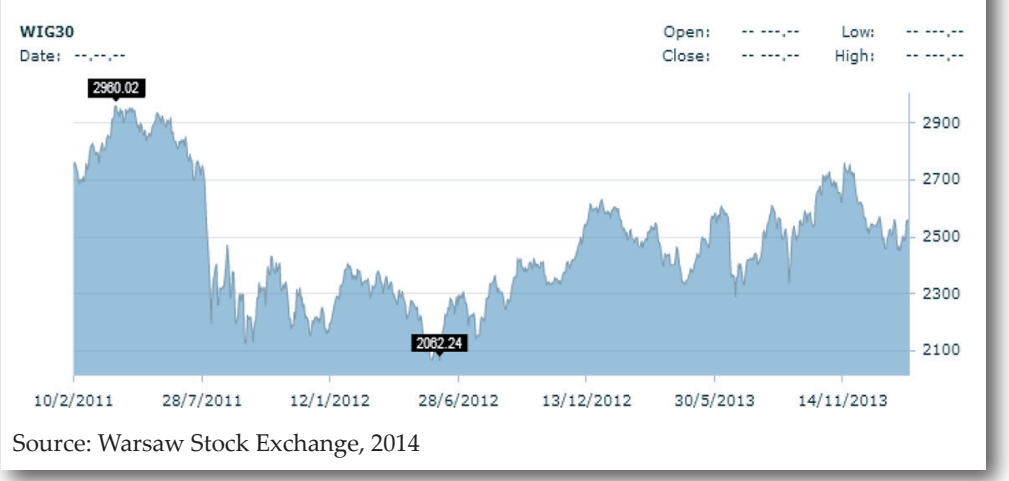

Based on the Graph 4 above, it may be observed that the WIG30 index reached its peak value on 1.4.2011 with a total of 2960,2 index points, whereas the lowest value was reached on 1.6.2012. with a total of 2062,04 index points. Compared to the presented indices of the Belgrade and Zagreb Stock Exchanges, a similar trend of all three indices can be observed, in terms of the reached maximum and minimum values.

\section{Comparative Analysis of Operations on the Observed Stock Exchanges}

The size of the Serbian capital market in relation to the countries in the region will be estimated by means of market capitalization ratio. More precisely, this indicator equals market value of listed shares divided by gross domestic product (MC/GDP). Although large markets do not necessarily function efficiently, this ration is frequently used in literature to indicate the development of a stock market, under the assumption that the size of the stock exchange is positively correlated to the possibility of mobilizing capital and diversifying risks (Levine and Zervos, 1998). Table 4 below shows market capitalization ratio of the observed countries in the region. 
Na osnovu Tabele 4 može se uočiti da je zaključno sa 2007. godinom na svim berzama prisutan rast tržišne kapitalizacije $\mathrm{u}$ odnosu na GDP. Međutim, pojava recesije, u drugoj polovini 2008. godine, uslovila je pad vrednosti ovog pokazatelja, ne samo na Beogradskoj berzi, već i na ostalim tržištima $\mathrm{u}$ regionu. Usporavanje rasta svetske privrede $\mathrm{i}$ nepovoljne makroekonmske tendencije $\mathrm{u}$ zemaljama EU uzrokovale su dalja negativna ekonomska kretanja i u srpskoj privredi. Stoga je 2011. godina kako za tržište kapitala tako i za ukupnu privredu Srbije bila lošija u odnosu na prethodne godine. Udeo tržišne kapitalizacije u bruto domaćem proizvodu u Srbiji i zemljama $\mathrm{u}$ regionu u proseku za oko 50\% zaostaje za svetskim prosekom.

U cilju ilustracije stepena likvidnosti Beogradske berze, $\mathrm{u}$ Tabeli 5 dat je prikaz učešća prometa na berzi u GDP (value traded ratio) za posmatrane zemlje u periodu od 2005. do 2011. godine. Na osnovu podataka jasno uočavamo izdvajanje Poljske i Mađarske u odnosu na ostale zemlje u posmatranom periodu. Međutim, u celini posmatrano sva tržišta karakteriše nizak nivo likvidnosti. Evidentan je rast vrednosti ovog pokazatelja na svim berzama do 2007. godine. Usled globalne recesije dolazi do drastičnog smanjenja svih pokazatelja počev od 2008. godine (Jaksic, et al.). na nivou od $181,2 \%$ GDP-a. Iste godine $\mathrm{u}$ EU je dostigao rekordnih 158,8\%. Nakon globalne krize, krajem 2008. godine, došlo je do pada vrednosti ovog pokazatelja, s tim da se primećuje relativno veći pad u okviru EU nego u svetu. U 2011. godini ovaj pokazatelj se u slučaju EU zadržao na približno $38 \%$ svoje vrednosti iz 2007. godine, dok je u svetu taj odnos oko 55\%. U najuspešnijoj 2007. godini pokazatelj likvidnosti na Beogradskoj berzi je iznosio je svega $6,5 \%$. S obzirom da je nivo likvidnosti tržišta akcija jedan od važnih faktora prilikom donošenja investicionih odluka, jasno je da povećanje likvidnosti predstavlja neophodan uslov za privlačenje investitora.

\section{Zaključak}

Većina tržišta kapitala zemalja jugoistočne Evrope svrstavaju se među najmanja na svetu, te ona zajedno predstavljaju 0,2\% svetske tržišne kapitalizacije, 9,2\% nemačkog tržišta kapitala, a njihov godišnji promet je jednak desetodnevnom prometu akcija koje čine korpu indeks DAX nemačke berze. Period između 2006. i 2007. godine se smatra najvećim bumom na tržištu akcija. Međutim svetska finansijska kriza je dokaz da su vrednosti akcija na ovim tržištima bile precenjene.

Prilagođavanja funkcionisanja tržišta

Tabela 5: Odnos prometa i bruto domaćeg proizvoda u periodu od 2005. do 2012. godine (\% od GDP)

\begin{tabular}{|l|r|r|r|r|r|r|r|r|}
\hline Zemlja & \multicolumn{1}{c|}{$\mathbf{2 0 0 5}$} & \multicolumn{1}{c|}{$\mathbf{2 0 0 6}$} & \multicolumn{1}{c|}{$\mathbf{2 0 0 7}$} & \multicolumn{1}{c|}{$\mathbf{2 0 0 8}$} & \multicolumn{1}{c|}{$\mathbf{2 0 0 9}$} & \multicolumn{1}{c|}{$\mathbf{2 0 1 0}$} & $\mathbf{2 0 1 1}$ & $\mathbf{2 0 1 2}$ \\
\hline Bugarska & 4,80 & 4,54 & 13,05 & 3,19 & 0,82 & 0,41 & 0,50 & 0,71 \\
\hline Hrvatska & $\mathbf{1 , 7 8}$ & $\mathbf{3 , 6 6}$ & $\mathbf{6 , 8 9}$ & $\mathbf{4 , 9 2}$ & $\mathbf{2 , 2 4}$ & $\mathbf{1 , 7 0}$ & $\mathbf{1 , 5 8}$ & $\mathbf{0 , 8 3}$ \\
\hline Mađarska & 21,67 & 27,71 & 34,90 & 19,97 & 20,48 & 20,58 & 13,90 & 8,73 \\
\hline Makedonija & 1,62 & 2,98 & $\mathbf{6 , 1 8}$ & 1,59 & 0,66 & 0,39 & 0,50 & 0,32 \\
\hline Crna Gora & 4,61 & 10,69 & 10,23 & 2,33 & 7,91 & 0,75 & 1,71 & 0,98 \\
\hline Srbija & $\mathbf{2 , 6 4}$ & $\mathbf{4 , 5 9}$ & $\mathbf{6 , 5 5}$ & $\mathbf{2 , 6 1}$ & $\mathbf{1 , 4 0}$ & $\mathbf{0 , 6 2}$ & $\mathbf{0 , 7 4}$ & $\mathbf{0 , 7 7}$ \\
\hline Poljska & $\mathbf{9 , 8 6}$ & $\mathbf{1 6 , 1 1}$ & $\mathbf{1 9 , 8 8}$ & $\mathbf{1 2 , 8 4}$ & $\mathbf{1 2 , 9 4}$ & $\mathbf{1 6 , 4 9}$ & $\mathbf{1 8 , 6 0}$ & $\mathbf{1 3 , 7 3}$ \\
\hline Slovenija & 2,21 & 2,62 & 5,74 & 2,58 & 2,08 & 0,58 & 1,03 & 0,88 \\
\hline
\end{tabular}

Izvor: The World Bank

U najrazvijenim svetskim ekonomijama ukupni godišnji promet akcijama na berzama prevazilazi vrednost njihovog bruto domaćeg proizvoda. U 2007. godini pokazatelj je bio kapitala u sve tri zemlje vodili su iskusni timovi iz oblasti berzi i berzanskog poslovanja. Osnova je bila stvoriti jaka tržišta preko kojih će kompanije, nezavisno od veličine, moći da 
Table 4: Comparative review of the countries in the region according to their capital market size, in the period from 2005 to 2012 (\% of GDP)

\begin{tabular}{|l|r|r|r|r|r|r|r|r|}
\hline Country & \multicolumn{1}{c|}{$\mathbf{2 0 0 5}$} & \multicolumn{1}{c|}{$\mathbf{2 0 0 6}$} & \multicolumn{1}{c|}{$\mathbf{2 0 0 7}$} & \multicolumn{1}{c|}{$\mathbf{2 0 0 8}$} & \multicolumn{1}{c|}{$\mathbf{2 0 0 9}$} & \multicolumn{1}{c|}{$\mathbf{2 0 1 0}$} & \multicolumn{1}{c|}{$\mathbf{2 0 1 1}$} & \multicolumn{1}{c|}{$\mathbf{2 0 1 2}$} \\
\hline Bulgaria & 17.60 & 31.09 & 51.75 & 17.09 & 14.63 & 15.25 & 15.42 & 13.08 \\
\hline Croatia & $\mathbf{2 8 . 8 2}$ & $\mathbf{5 8 . 1 8}$ & $\mathbf{1 1 1 . 1 9}$ & $\mathbf{3 8 . 3 2}$ & $\mathbf{4 0 . 4 1}$ & $\mathbf{4 0 . 9 4}$ & $\mathbf{3 4 . 1 4}$ & $\mathbf{3 6 . 4}$ \\
\hline Hungary & 29.53 & 37.26 & 35.01 & 12.05 & 22.34 & 21.54 & 13.41 & 16.92 \\
\hline Macedonia & 10.79 & 16.74 & 33.28 & 8.37 & 9.90 & 6.96 & 5.56 & 5.82 \\
\hline Montenegro & 46.46 & $\mathbf{6 5 . 0 4}$ & 100.82 & 63.34 & 103.57 & 87.67 & 73.00 & 87.5 \\
\hline Serbia & $\mathbf{2 1 . 4 3}$ & $\mathbf{3 7 . 5 9}$ & $\mathbf{6 1 . 4 4}$ & $\mathbf{2 5 . 4 7}$ & $\mathbf{2 8 . 7 0}$ & $\mathbf{2 5 . 2 2}$ & $\mathbf{1 8 . 5 7}$ & $\mathbf{1 9 . 8 7}$ \\
\hline Poland & $\mathbf{3 0 . 8 9}$ & $\mathbf{4 3 . 6 3}$ & $\mathbf{4 8 . 7 4}$ & $\mathbf{1 7 . 1 4}$ & $\mathbf{3 1 . 4}$ & $\mathbf{4 0 . 4 9}$ & $\mathbf{2 6 . 8 1}$ & $\mathbf{3 6 . 2 7}$ \\
\hline Slovenia & 22.11 & 38.98 & 61.22 & 21.56 & 23.99 & 20.10 & 12.59 & 14.30 \\
\hline
\end{tabular}

Source: The World Bank

Based on Table 4 it may be observed that, concluding with 2007, all stock exchanges recorded an upward trend of market capitalization in relation to GDP. However, the outbreak of the recession, in the second half of 2008, caused a decline of this indicator, not only at the Belgrade Stock Exchange, but in other markets in the region as well. The slowed down growth of the global economy and unfavorable macroeconomic tendencies in the EU countries caused further adverse economic trends in the Serbian economy, too. Thus, 2011 was worse than the previous years both in terms of the capital market and the overall economy of Serbia. The share of market capitalization in
GDP in Serbia and other countries in the region lags behind the global average by about $50 \%$, on average.

With a view to illustrating the liquidity level of the Belgrade Stock Exchange, Table 5 provides value traded ratio for the observed countries in the period from 2005 to 2011. The data clearly suggest that Poland and Hungary are set apart from the other countries in the observed period. However, on the whole all markets are characterized by low liquidity levels. There is an evident growth of this indicator on all stock exchanges by 2007. Due to the global recession, there is a drastic decrease of all indicators starting from 2008 (Jaksic, et al.).

Table 5: Value traded ratio in the period from 2005 to 2012 (\% of GDP)

\begin{tabular}{|l|r|r|r|r|r|r|r|r|}
\hline Country & \multicolumn{1}{c|}{$\mathbf{2 0 0 5}$} & \multicolumn{1}{c|}{$\mathbf{2 0 0 6}$} & \multicolumn{1}{c|}{$\mathbf{2 0 0 7}$} & \multicolumn{1}{c|}{$\mathbf{2 0 0 8}$} & \multicolumn{1}{c|}{$\mathbf{2 0 0 9}$} & \multicolumn{1}{c|}{$\mathbf{2 0 1 0}$} & \multicolumn{1}{c|}{$\mathbf{2 0 1 1}$} & \multicolumn{1}{c|}{$\mathbf{2 0 1 2}$} \\
\hline Bulgaria & 4.80 & 4.54 & 13.05 & 3.19 & 0.82 & 0.41 & 0.50 & 0.71 \\
\hline Croatia & $\mathbf{1 . 7 8}$ & $\mathbf{3 . 6 6}$ & $\mathbf{6 . 8 9}$ & $\mathbf{4 . 9 2}$ & $\mathbf{2 . 2 4}$ & $\mathbf{1 . 7 0}$ & $\mathbf{1 . 5 8}$ & $\mathbf{0 . 8 3}$ \\
\hline Hungary & 21.67 & 27.71 & 34.90 & 19.97 & 20.48 & 20.58 & 13.90 & 8.73 \\
\hline Macedonia & 1.62 & 2.98 & 6.18 & 1.59 & 0.66 & 0.39 & 0.50 & 0.32 \\
\hline Montenegro & 4.61 & 10.69 & 10.23 & 2.33 & 7.91 & 0.75 & 1.71 & 0.98 \\
\hline Serbia & $\mathbf{2 . 6 4}$ & $\mathbf{4 . 5 9}$ & $\mathbf{6 . 5 5}$ & $\mathbf{2 . 6 1}$ & $\mathbf{1 . 4 0}$ & $\mathbf{0 . 6 2}$ & $\mathbf{0 . 7 4}$ & $\mathbf{0 . 7 7}$ \\
\hline Poland & $\mathbf{9 . 8 6}$ & $\mathbf{1 6 . 1 1}$ & $\mathbf{1 9 . 8 8}$ & $\mathbf{1 2 . 8 4}$ & $\mathbf{1 2 . 9 4}$ & $\mathbf{1 6 . 4 9}$ & $\mathbf{1 8 . 6 0}$ & $\mathbf{1 3 . 7 3}$ \\
\hline Slovenia & 2.21 & 2.62 & 5.74 & 2.58 & 2.08 & 0.58 & 1.03 & 0.88 \\
\hline
\end{tabular}


dođu do svežeg kapitala. Na WSE je još 2003. godine za tu svrhu „privatizovano“ preko IPO šest kompanija. Nakon pristupa u EU taj broj se stalno povećavao, što je uticalo na nagli rast broja likvidnih akcija, kao i na rast ukupne tržišne kapitalizacije. Na tržištima jugoistočne Evrope, poput Hrvatske i Srbije, ta ideja je došla nešto kasnije. Međutim, to ne bi bio problem da je ista realizovana 2006/2007. godine kada je najveći broj javnih preduzeća privatizovan. $\mathrm{Na}$ teritoriji Republike Srbije ni jedna privatizacija nije sprovedena preko BSE. Na hrvatskom tržištu, situacija je bila nešto drugačija. Uz reformu Hrvatskog fonda za privatizaciju (HFP), započeto je formiranje zatvorenog investicijskog fonda u koji su uvršćene akcije kompanija u državnom vlasništvu koje se već kotiraju na berzi. Nakon toga je sprovedena inicijalna javna ponuda akcija tog fonda, što je u mnogome pomoglo bržoj realizaciji procesa privatizacije.

Sumirajući napred izneto, može se istaći da je strukturna neravnoteža u nivou razvijenosti banaka, nebankarskih finansijskih institucija i tržišta kapitala u Srbiji izraženija u odnosu na ostale zemlje koje su prošle kroz proces tranzicije. Proces tranzicije je podrazumevao, osim restrukturiranja bankarskog sektora u skladu sa potrebama tržišne privrede, i izgradnju drugih segmenata finansijskog sistema - nedepozitnih finansijskih posrednika i tržišta kapitala. Nediversifikovana struktura nedepozitnih finansijskih institucija i plitko tržište kapitala su ogledalo ekonomskih prilika u zemlji.

Na kraju se može zaključiti da berzansko tržište predstavlja važno područje interesovanja kreatora državne politike i integralni deo državnih strategija usmerenih na ostvarivanje ekonomskog rasta i razvoja. Globalizacija i deregulacija finansijskih tokova i brojne finansijske inovacije su doprinele da finansiranje ekonomskog rasta i razvoja postane kompleksna oblast istraživanja. Globalno posmatrano, posebno u vreme ekonomske krize, nacionalne ekonomije ne mogu samostalno da zadovolje stalno rastuće potrebe za dobrima i uslugama. Stoga se nužno nameće potreba privlačenja privatnih investicija preko berzanskog tržišta. 
In the most developed global economies, the total annual turnover of shares on stock exchanges exceeds the value of their gross domestic product. In 2007 this indicator amounted to $181.2 \%$ of GDP. That same year, in the EU it reached the unprecedented $158.8 \%$. After the outbreak of the global crisis, in late 2008, the values of this indicator dropped, the decrease being relatively more substantial in the EU than in the world. In 2011 this indicator in the EU stayed at approximately $38 \%$ of its value from 2007, whereas in the world this ratio was about $55 \%$. In the most successful year, the liquidity indicator at the Belgrade Stock Exchange amounted to just $6.5 \%$. Given that the stock market liquidity is one of the significant factors in the process of investment decisionmaking, clearly a boost in liquidity represents a necessary prerequisite for attracting investors.

\section{Conclusion}

The majority of capital markets in the Southeastern Europe countries are ranked among the smallest in the world, hence together they represent only $0.2 \%$ of the world's market capitalization, $9.2 \%$ of the German capital market, and their annual turnover equals a ten-day turnover of shares in the DAX index basket at the German stock exchange. The period between 2006 and 2007 is considered the biggest boom at the stock market. Nevertheless, the global financial crisis has proven that the value of the shares at these markets was overestimated.

The adjustments in the functioning of capital markets in these three countries were led by teams experienced in stock exchanges and stock exchange operations. The foundation was to create strong markets enabling companies, regardless of their size, to acquire fresh capital. At the WSE already in 2003 six companies were "privatized" through IPOs for that purpose. After joining the EU, this number kept increasing, having influenced a sudden growth in the number of liquid shares, and the increase of total market capitalization. At the
SEE markets, like Croatia and Serbia, this idea appeared somewhat later. Yet, this would not have been a problem if it had been realized in 2006/2007, when the majority of public company

ies underwent privatization. In the Republic of Serbia not a single privatization process was implemented through the BSE. On the Croatian market, the situation was somewhat different. Along with the reform of the Croatian Privatization Fund (CPF), the formation of a closed-end investment fund was launched, with a view to including shares of state-owned companies already quoted on the stock exchange. This was followed by the initial public offering of that fund's shares, which largely facilitated a quicker implementation of the privatization process.

To summarize, we underline that the structural misbalance when it comes to the development of banks, non-banking financial institutions and capital markets is more prominent in Serbia than in other countries which underwent the transition process. The transition process implied, in addition to the restructuring of the banking sector according to the market economy's requirements, the construction of other segments of the financial system - non-deposit financial intermediaries and the capital market. Undiversified structure of non-deposit financial institutions and the shallow capital market perfectly reflect the economic circumstances in the country.

Finally, it may be concluded that the stock exchange market represents an important field of interest for the state policy makers, being an integral part of the government strategies aimed at achieving economic growth and development. Globalization and financial flows deregulation, along with numerous financial innovations, made a complex research field out of economic growth and development finance. Globally speaking, especially at times of an economic crisis, national economies are unable to independently meet the growing demand for goods and services. This is what generates the necessity of attracting private investments through the stock exchange market. 


\section{Literatura / References}

1. Burhop C. 2006. Did banks cause the German industrialization. Explorations in Economic History 43 (1): 39-63.

2. Calderón C., Liu L. 2003. The Direction of Causality between Financial Development and Economic Growth, Journal of Development Economics, Elsevier 72 (1): 321-334

3. Dugalić V., Štimac M. 2005. Osnove berzanskog poslovanja. Beograd: Stubovi kulture.

4. Jaksic M., Grbic M., Djindjic S. 2013. Financial system transition in Serbia: the first decade of the XXIst century, Actual Problems of Economics, No. 12 (150): 578-587.

5. Jakšić S. 2007. Primjena Markowitzeve teorije na tržište dionica zagrebačke burze, Zbornik Ekonomskog fakulteta u Zagrebu (5): 331-344.

6. Levine R., Zervos S. 1998. Stock Markets, Banks, and Economic Growth, The American Economic Review 88 (3): 537-558.

7. Malinic D. 2009. Savremeni izazovi integralnog istraživanja kvaliteta finansijskih izveštaja, Ekonomika, 57 (3-4): 156-174.

8. Odedokun M. O. 1996. Alternative econometric approaches for analyzing the role of the financial sector in economic growth: Time-series evidence from LDCs. Journal of Development Economics 50 (1): 119-146.
9. Pečarić M., Arnerić J., Radić M. 2012. Komparativna analiza stupnja financijske integracije tržišta kapitala Hrvatske i zemalja CEE s tržištem EU-a. Ekonomski fakultet Sveučilišta u Rijeci: 111-148.

10. Proniewski M., Niedźwiecki A. 2009. Giełda Papierów Warto w Warszawie- ujęcie retrospektywne, Drukarnia Biały Kruk, Białystok

11. Rousseau P., Wachtel P. 1998. Financial intermediation and Economic Performance. Historical Evidence From Five Industrialized Countries. Journal of Money, Market and Banking 30 (4): 657-678.

12. Rousseau P. L., Sylla, R. 2005. Emerging Financial Markets and Early US Growth. Explorations in Economic History, 42 (1): 1-26.

13. Fruk M. i Huljak I. 2004. Testiranje SharpeLinterova modela na Zagrebaèkoj burzi. Financijska teorija i praksa 28 (1): 77-91.

\section{Internet izvori / Internet sources}

14. Beogradska berza 2012. Metodologija za izračunavanje indeksa BELEX15 preuzeto 15.1.2014. g. sa sajta http://www.belex.rs/ files/trgovanje/BELEX15_metodologija.pdf 
15. Beogradska berza 2014. Kretanje vrednosti indeksa u periodu od 2011-2014. preuzeto 19.1.2014. g. sa sajta http://www.belex.rs/ trgovanje/indeksi/svi/indeksi\#

16. Godišnji izveštaj o poslovanju u 2012. godini, preuzeto 25.12.2013. g. sa sajta: http://www. belex.rs/files/proizvodi_i_usluge/GI_2012.pdf

17. Zagrebačka berza 2013. Odluka o indeksu CROBEX10. preuzeto 19.1.2014. g. sa sajta: http://zse.hr/UserDocsImages/dokumenti_ indeksi/CROBEX10_20130823153618-201308-Odluka-o-indeksu-CROBEX10.pdf

18. Zagrebačka berza 2014. Kretanje vrednosti indeksa u periodu od 2011-2014 preuzeto 19.1.2014. g. sa sajta http://zse.hr/default. aspx? $\mathrm{id}=44101$ \&index=CROBEX10

19. Statut Zagrebačke berze, preuzeto 1.10.2014. g. sa sajta: http://zse.hr/default. aspx? id $=32902$

20.Schmiedecke K. I. 2008. Strukturirani proizvodi. 18. godišnja konferencija Zagrebačke berze, preuzeto 18.1.2014. g. sa sajta: http://zse.hr/UserDocsImages/konf/ Iskra\%20Kalodera\%20Schmiedecke.pdf
21. Sieradzki R. 2013. Does it pay to invest in IPOs? Evidence from the Warsaw Stock Exchange. National Bank of Poland. preuzeto 19.1.2014. g. sa sajta: http://www. nbp.pl/publikacje/materialy_i_studia/139_ en.pdf

22. Chuda J., Jara M., Sieńko P. (ed.) 2012. The role of stock exchanges in transition economies, preuzeto 15.1.2014. g. sa sajta: http://uek.krakow.pl/ files/common/dwm/stair-discussion-papers/ CUEDP_013_CHUDA.pdf

23. Centralni registar, depo i kliring hartija od vrednosti- CrHoV 2006. Izveštaj o poslovanju. preuzeto 18.1.2014. g. sa saijta: http://www.crhov.rs/rezultatiposlovanja/ Izvestaj_o_poslovanju_2006.pdf

24. Warsaw Stock Exchange 2013. Warsaw Stock Exchange Indices. preuzeto 18.1.2014. sa saijta: http://www.gpw.pl/indeksy_ gieldowe_en 